\title{
Genetic and Molecular Coordinates of Neuroendocrine Lung Tumors, with Emphasis on Small-cell Lung Carcinomas
}

\author{
Marilena K. Koutsami, ${ }^{1}$ Ipatia Doussis-Anagnostopoulou, ${ }^{1}$ Athanasios G. Papavassiliou, ${ }^{2}$ \\ and Vassilis G. Gorgoulis ${ }^{1}$ \\ ${ }^{1}$ Department of Histology and Embryology, School of Medicine, University of Athens, Athens, Greece \\ ${ }^{2}$ Department of Biochemistry, School of Medicine, University of Patras, Patras, Greece \\ Contributed by A.G. Papavassiliou. Accepted June 26, 2002
}

\begin{abstract}
The aim of this review is to present the advances in our understanding of the progression of tumorigenesis in neuroendocrine lung tumors. Current information on established and putative diagnostic and prognostic markers of neuroendocrine tumors are evaluated, with a special reference to
\end{abstract}

small-cell lung carcinoma, due to its higher incidence and aggressive behavior. The genetic and molecular changes that accompany these neoplasms are highlighted, and factors that influence cell-cycle progression, apoptosis, drug resistance, and escape from immune surveillance are critically assessed.

\section{Introduction}

Lung cancer is one of the leading fatal malignancies in the Western world. Two major histopathologic groups are recognized: small-cell lung carcinomas (SCLCs), accounting for approximately $20-25 \%$ of the cases, and non-small-cell lung carcinomas (NSCLCs), representing the majority of lung malignancies (1).

SCLCs demonstrate neuroendocrine (NE) characteristics and belong to the NE lung tumors, along with typical carcinoids (TCs), atypical carcinoids (ACs), and large-cell NE carcinomas (LCNECs) of the lung (2-5). Inconsistency in the terms in the literature regarding these entities has created confusion and reveals the difficulty in their identification (6), making necessary the use of well-defined criteria. A number of features, distinguishing TCs from ACs, as well as LCNECs from SCLCs, are presented in Table $1(2,7)$. This distinction is of clinical importance, because the tumor grade differs. Thus, TCs are low-grade tumors (grade 1), ACs represent the intermediate grade tumors (grade 2) $(3,7)$, and SCLCs and LCNECs are characterized as high-grade tumors (grade 3$)(3,7,8)$, with the clinical aggressiveness of LCNECs lying between ACs and SCLCs (8-12). Interestingly, large-cell carcinomas with NE characteristics have

Address correspondence and reprint requests to: V. G. Gorgoulis, and A. G. Papavassiliou, 53 Antaiou Str., Lamprini, Ano Patisia, GR-11146 Athens, Greece.

Fax: ++30-10-6535894 or ++30-610-996110;

e-mail: histoclub@ath.forthnet.gr or papavas@med.upatras.gr a poorer prognosis than classic large-cell carcinomas (12). Thus, TCs and SCLCs may be regarded as the two extremes of malignancy among NE lung tumors.

The genetic "steps" that lead to NE differentiation either in normal lung epithelium or in lung tumors still remain elusive. Probably, among the plethora of regulatory pathways, some eventually enhance the ectopic expression of a large number of NE genes, an event that will lead to formation of SCLC (13). There are several reports proposing the modulatory implication of arginine-vasopressin, pro-opiomelanocortin, and gastrin-releasing peptide genes in the induction of SCLC NE character (13-16). This process entails the activation of several repressors, enhancers, and tissue-specific factors (13). The above neuropeptides-as well as neuromedin B, neurotensin, and cholecystokinin-are expressed in SCLC, regulating its progression $(13,17,18)$. Specifically, their binding to their cognate receptors induces intracellular calcium mobilization via $\mathrm{G}_{\mathrm{q}}$ proteins. Remarkably, the neuropeptide receptors bear extensive homology with the superfamily of heterotrimeric $G$ protein-coupled, seven transmembrane (TM)-spanning receptors. By participating in the autocrine signal pathways of SCLC, this mobilization seems to enhance tumor growth (13).

Although all types of lung cancer are related to smoking, this association is even stronger for SCLC and LCNEC (19-23); on the other hand, smoking is unlikely to be related with carcinoid development 
Table 1. 1999 WHO criteria for diagnosis of NE tumors

\begin{tabular}{|c|c|}
\hline Histologic Type & Criteria \\
\hline Typical carcinoid & $\begin{array}{l}\text { Carcinoid morphology, } \\
\geq 0.5 \mathrm{~cm},<2 \text { mitoses/ } \\
2 \mathrm{~mm}^{2} \text { (10 HPFs), } \\
\text { without necrosis }\end{array}$ \\
\hline Atypical carcinoid & $\begin{array}{l}\text { Carcinoid morphology, } \\
2-10 \text { mitoses } / 2 \mathrm{~mm}^{2} \\
\text { (10 HPFs), and/or necrosis }\end{array}$ \\
\hline Large-cell NE carcinoma & $\begin{array}{l}\text { NE morphology (organoid } \\
\text { nesting, palisading, } \\
\text { rosettes, trabeculae), } \\
\geq 10 \text { mitoses } / 2 \mathrm{~mm}^{2} \\
\text { ( } 10 \mathrm{HPFs} \text { ), large zones of } \\
\text { necrosis, cytologic } \\
\text { characteristics of a NSCLC, } \\
\text { positive immunohisto- } \\
\text { chemical staining for one } \\
\text { or more NE markers, } \\
\text { and/or NE granules by } \\
\text { electron microscopy }\end{array}$ \\
\hline Small-cell carcinoma & $\begin{array}{l}\text { Small size and specific } \\
\text { cytologic characteristics, } \\
\geq 11 \text { mitoses } / 2 \mathrm{~mm}^{2} \\
\text { (10 HPFs), large zones } \\
\text { of necrosis }\end{array}$ \\
\hline
\end{tabular}

Abbreviations: HPF, high power fields; NE, neuroendocrine.

$(23,24)$. In pathophysiologic terms, the relation of tobacco to SCLC may be explained by the correlation between the usually proximal anatomic location of SCLC and the size of tobacco particles. Big particles of tobacco, containing large amounts of carcinogens, tend to rest proximally and induce carcinogenesis at that site (22). Interestingly, female smokers have a higher relative risk for developing SCLC than male smokers (19), and quitting smoking does not seem to influence the risk of SCLC occurrence (21).

There has been a decline in the incidence of lung cancer among men in the United States, Northern Europe, and Australia, probably due to changes observed in the smoking habits (25), but this is not the case for women and for the population of Southern and Eastern Europe. Male gender is associated with a greater incidence of aggressive NE tumors, whereas TCs affect females more frequently $(26,27)$. Carcinoids demonstrated a raise in incidence since the 1980s, which may partially be attributed to the progress of diagnostic methods and the higher awareness of the public (27).

The scope of this review is to unravel the genetic and molecular modifications that take place in lung NE tumors during their progression. The need for early detection and treatment represents a challenge for researchers to discover new, putative diagnostic and prognostic markers, besides the established ones, that will contribute to better management of these malignancies. Similarly, understanding of the mechanisms involved in multidrug resistance will offer novel targets for chemotherapy and gene therapy.

\section{Genetic Changes}

Chromosomal Abnormalities

Several studies have investigated the presence of chromosomal aberrations in SCLC. The most frequent chromosomal abnormalities found in SCLC are either losses on $3 p, 1 q 23,4 q, 5 q, 9 q 22.33-32$, $10 p 15.3,10 q, 13 q 34,16 q$, and $17 p$ or gains on $3 q, 5 p$, $8 q, 17 q$, and $19 q(28-38)$. Notably, these lesions often take place simultaneously, thus inactivating several growth-inhibitory pathways, which could partially explain the aggressive phenotype of these tumors (30). It is noteworthy that gain on $18 q$, which associates with overexpression of $\mathrm{Bcl}-2$, and losses on $2 p$ and $16 q$ have been exclusively identified in highgrade NE tumors (39). Amplification at 1p22-32 $(L-m y c), 2 p 24-25(N-m y c)$, and 3q22-25, as well as loss at $18 p$ have been demonstrated in SCLCs, as well as in variant SCLC cell lines $(32,40)$.

$3 p$ deletion represents the best-documented lesion of SCLC $(28,30,32,34-36,38)$. Several putative tumor-suppressor genes (TSGs) have been identified within this region. It has been shown that loss of FHIT (Fragile Histidine Triad), a candidate TSG located at $3 p 14.2$, occurs in the majority of SCLCs as well as in preneoplastic lesions, such as bronchial dysplasia and metaplasia (41 and references therein, 42,43). FHIT protein is expressed in normal lung epithelium; reduction or absence of the protein is observed in SCLCs and bronchial preneoplastic lesions. This may be indicative of its early inactivation in the progression of lung carcinogenesis $(44,45)$. Chromosome $3 p$ has been recently considered to be a target of hypermethylation in SCLCs. During carcinogenesis, aberrant methylation at $\mathrm{CpG}$ sites leads to gene silencing (23). The ras association domain family $1 \mathrm{~A}$ gene (RASSF1A), a TSG located in $3 p 21.3$, is inactivated through promoter hypermethylation in the majority of SCLCs (46), although, when introduced in tumor cells, it suppresses the malignant phenotype (47). $3 p 24$ region harbors the $R A R \beta$ (retinoic acid receptor $\beta$ ) gene, which is also inactivated in SCLCs by hypermethylation of its $R A R \beta \mathrm{P} 2$ gene promoter (48). According to Onuki et al. (49), loss of heterozygosity at $3 p 21,3 p 22-24$, and FHIT gene bears some adverse prognostic significance for SCLCs. Considering that $3 p$ deletion is an early molecular event in SCLC carcinogenesis, further studies are needed to elucidate whether aberrant methylation is a parallel carcinogenetic process to $3 p$ deletion.

Another relatively frequent DNA loss is that of $10 q(30,34-36)$. It seems to ally with tumor progression, a finding in accordance with the high aggressiveness of SCLC (30) due to the presence of a variety of TSGs located in this region (23). Several putative TSGs are found within this region. DMBT1 
(deleted in malignant brain tumors 1), a candidate TSG located in 10q25.3-26.1, is frequently inactivated in SCLCs (23). Additionally, PTEN/MMAC1 (phosphatase and tensin homologue/mutated in multiple advanced cancers), a newly identified TSG located in 10q23.3, is frequently deleted in SCLC $(23,31)$. The MXI1 TSG, located in 10q24-25, is considered to be a negative regulator of myc, whose amplification and overexpression are very common in advanced SCLCs (50).

$5 q$ region, harboring the $M C C$ (mutated in colon cancer), APC (adenomatous polyposis coli), DOC2 (double C2), and IRFI (interferon regulatory factor-1) TSGs, is often deleted in SCLCs $(23,30,33,35,49,51-53)$. The role of these genes in lung carcinogenesis is not yet fully understood (54). Most deletions are identified at $5 q 21$, where loss of heterozygosity relates to poor prognosis (49). However, in some cases the telomeric locus 5q33-35 is the target, suggesting the presence of at least two different TSGs in the region (53). The demonstration of loss in the $5 q$ region in metastatic SCLCs, but not in primary tumors, implies a late involvement of the genes of the region in lung carcinogenesis (53).

Loss of 4q11-23 centromeric region, which is the locus of $c$-kit gene, has been also demonstrated $(30,55)$. Moreover, allelic losses of 4q33-34, 4q25-26, and 4p15.1-15.3 appear frequently in SCLCs (56). A concordance between allelic loss on $5 q$ and $4 q 12$ regions has been observed; however, further studies are required to clarify a possible cooperation between the genes located at $4 q 12$ and $5 q$ in SCLC development (29). $9 p$ deletion occurs in a region near to interferon genes and its involvement in SCL carcinogenesis should be further examined $(54,57)$. $9 p 21$ locus harbors the CDKN2 p16 $6^{I N K 4 A}$ gene, whose product is a pivotal cell-cycle negative regulator (see below). Loss of heterozygosity at $9 p 21$ has been associated with short life expectancy (49), probably due to cell-cycle deregulation. Finally, Merlo et al. (57) have detected two putative suppressor loci on chromosome 6 in primary SCLCs. Losses of $13 q$ and $17 p$ concern mainly the $R b$ and $p 53$ genes, respectively, which are discussed below.

LCNECs display deletions at chromosomes $3 p$, $4 q, 5 q, 10 q, 13 q$, and $15 q$, and gains at $5 p$ and $6 p$ $(37,58)$. Ullmann et al. (28) have also observed a high frequency of similar alterations at $3 p, 5 q, 5 p$, and $13 q$ in SCLCs and LCNECs, which are related to a poor clinical outcome of these carcinomas. Deletions of $10 q, 16 q$, and $17 p$ are more common in SCLCs than in LCNECs (37). Interestingly, Debelenko et al. (59) have observed in a single case of LCNEC mutation of the MEN1 (multiple endocrine neoplasia 1) gene, which represents a usual lesion of carcinoids. This finding requires further investigation.

In comparison to high-grade NE tumors, TCs and ACs display fewer chromosomal lesions, explaining their better prognosis (28). In contrast to SCLCs, TCs display a strong FHIT protein expression (45). According to several reports, ACs exhibit an intermediate level of genetic lesions in $3 p, 9 p, 17 p, 3 p 14.2$, and $5 q$ in comparison with TCs, SCLCs, and LCNECs $(28,45,49,60,61)$. In addition, ACs are usually accompanied by losses in $10 q$ and $13 q(58)$. TCs and ACs have frequent aberrations on chromosome $11 q$, which includes the MEN1 gene domain $(28,49,62-64)$, but this is not the case for SCLC tumors (58). According to some researchers, loss of heterozygosity of $11 q$ is more common in ACs than in TCs $(61,65)$.

\section{Microsatellite Alterations}

This type of genomic instability seems to be present in a variety of malignancies, including SCLCs (23 and references therein). Compared to replication error-type instability, microsatellite alterations (MAs) affect larger tandem repeat DNA sequences (tetra- or pentanucleotides), involve only a few loci, and lack mutations in the mismatch-repair genes hMLH1, hPMS1, hPMS2, and hMSH2 (66). MAs are more frequent in SCLCs than in other histologic types of lung cancer $(51,67)$ and may be detected in plasma DNA of SCLC patients $(23,67-71)$. Interestingly, a significant incidence of microsatellite instability is also present in the adjacent normal epithelium of SCLCs, indicating the great extend of genetic damage in these carcinomas (23). The prognostic role of MAs is still a matter of debate $(68,71)$. Neither TCs nor ACs present microsatellite instability at chromosome $3 p$ loci, and this probably reflects a different carcinogenetic evolution in these tumors than that of SCLCs (67).

\section{Molecular Alterations (Tables 2 and 3) Extracellular and Cell Membrane Factors}

Growth Factors and Growth Factor Receptors Epidermal growth factor (EGF), as well as transforming growth factor- $\alpha$ (TGF- $\alpha$ ), amphiregulin (AR), CRIPTO, heregulin, and heparin-binding EGF are members of the EGF family. The actions of EGF, TGF- $\alpha$, and AR are mediated through the EGF receptor (EGFR), which implies parallel functional roles in carcinogenesis (72). EGF signaling plays a modulatory role in tumor cell adhesion to extracellular matrix (ECM) proteins via integrins, either by inhibiting or by stimulating this process (73). A synergistic interaction has been observed between EGF and thrombospondin-1 (TSP-1), an adhesive protein (see below), which leads to neurotypic differentiation and growth suppression of SCLCs via $\alpha 3 \beta 1$ integrin-mediated adhesion of SCLC cells on TSP-1 (74). The interaction between these molecules in SCLCs must be further explored.

EGFR, the product of the HER-1 oncogene, is a 170-kD TM glycoprotein with intracellular tyrosine kinase activity. Together with c-erbB-2, c-erbB-3, and c-erbB-4 they form the class I GFRs (75). There is a lot of controversy on whether SCLCs express EGFR or not $(23,76-78)$. c-erbB-2, also known as HER-2/neu, is an oncogene located in 17p11.2-p12 and its product is pl85 (75). Micke et al. (79) have observed that c-erbB-2 
Table 2. The status of the various factors in relation to the spectrum of NE tumors

\begin{tabular}{|c|c|c|}
\hline Factors & $\begin{array}{l}\text { Status in the Spectrum of } \\
\text { Aggressiveness (from TCs to SCLC) }\end{array}$ & References \\
\hline Aneuploidy & Increasing & 133,120 \\
\hline Bak & Highly expressed in carcinoids & 126 \\
\hline Bax & Decreasing & $23,112,124$ \\
\hline Bcl-2 & Increasing (decrease in metastatic SCLCs) & $23,112,124$ \\
\hline BCL-X & Expressed in TCs & 127 \\
\hline c-ets-1 & Highly expressed in high-grade NE tumors & 179 \\
\hline CD44S & Decreasing & 100 \\
\hline CD44v6 & Its loss is associated with aggressivity & 100 \\
\hline CD99 & Expressed only in TCs & $102-104$ \\
\hline Ki-67 labeling & Increasing & $114,193,194$ \\
\hline MCL-1 & Highly expressed in carcinoids & 126 \\
\hline PAI-1 & Increasing & 188 \\
\hline PAI-2 & Decreasing & 188 \\
\hline p53 & Increasing & $60,100,126$ \\
\hline $\mathrm{Rb}$ & Decreasing & $\begin{array}{l}11,38,58,134,135 \\
143-145,148-152\end{array}$ \\
\hline Topo II $\alpha$ & Increasing (although there are no reports for LCLCs) & $254,263,266$ \\
\hline $\mathrm{u}-\mathrm{PA}$ & Increasing & 187,188 \\
\hline
\end{tabular}

Abbreviations: SCLC, small-cell lung cancer; TC, typical carcinoids; LCLC, large-cell lung carcinoma.

expression correlates with poor prognosis in extensive disease or advanced stage of SCLCs.

The insulin-like growth factor (IGF) family consists of IGF-I, IGF-II, and relaxin. They bind to IGF-I and -II receptors, which bear tyrosine kinase activity (80). IGFs participate in mitogenesis, transformation, and survival of cells through endocrine, autocrine, and paracrine stimulation (81). Specifically, IGF-I mediates proliferation of the SCLC tumor cells via an autocrine feedback loop (82).

Cell Adhesion and Matrix Molecules Integrins are a group of TM glycoproteins with two subunits ( $\alpha$ and $\beta$ ) that participate mainly in cell-to-matrix interactions (83). In comparison to NSCLC cells, integrins in SCLC cells are underexpressed and are composed of fewer types. Integrin $\alpha 3 \beta 1$ is the predominant cell surface $\beta 1$ integrin molecule in SCLCs (84-86). $\alpha 3 \beta 1$ may be described as a multiple receptor: it interacts with laminin, collagen, entactin, and fibronectin at different receptor-binding domains in the presence of specific cations $(84,87-89)$. It is considered to be the most important laminin-binding integrin for the anchorage of alveolar and bronchial epithelial cells to the basement membrane of human lung (90). It has been reported that SCLC cells expressing $c-m y c$ display decreased expression of $\alpha 3 \beta 1$, an event that could explain the poor prognosis in SCLCs with c-myc overexpression (91).
Cadherins (CDHs) are TM glycoproteins containing dimeric, zipper-like adhesive structures that enable cellular interactions in the presence of calcium. SCLCs express several types of CDHs, including epithelial CDH (E-CDH). It has been suggested that $\mathrm{CDH}$-mediated adhesion is regulated by the small GTP-binding protein Rho in SCLCs (92). E-CDH forms a structural complex with the cytoplasmic $\beta$-catenin molecule. Impairments in the $\mathrm{E}-\mathrm{CDH} /$ catenin complex have been associated with tumor invasion and metastasis in cancer cells $(93,94)$. It has been shown that the E-CDH/catenin complex is expressed in most NE tumors, without relating to the histologic subtype and hence displaying no prognostic value. However, loss of complex expression was detected in isolated invasive tumor cells and it is probable that these cells may become the progenitors of a more aggressive population (95).

Catenins are intracellular cytoplasmic proteins comprising $\beta$ - and $\gamma$-catenin, which bind to E-CDH, and $\alpha$-catenin, which mediates the linkage of this complex to the cytoskeleton (96). Tyrosine phosphorylation of $\beta$-catenin may lead to an enhanced migration capacity of lung cancer cells (97). $\beta$-catenin cytoplasmic overexpression is associated with poor prognosis in SCLCs (98); however, its nuclear expression does not seem to have any prognostic significance in NE tumors (95). 
Table 3. Molecular markers with a postulated prognostic significance in NE tumors

\begin{tabular}{|c|c|c|}
\hline Proteins & Comments & References \\
\hline$\beta$-catenin & Its cytoplasmic overexpression has negative prognostic role in SCLCs & 98 \\
\hline Bcl-2 & Arguable prognostic role in SCLCs/adverse prognosis in large NE tumors & $121-123,125$ \\
\hline bFGF & Favorable prognostic significance in SCLCs & 210 \\
\hline CD44 & CD44v6 is correlated with tumor aggressiveness in NE tumors & 100 \\
\hline c-erbB-2 & Poor prognosis in advanced SCLCs & 79 \\
\hline c-myc & Negative prognostic value in SCLCs & 160,163 \\
\hline MMP-3 & Unfavorable prognostic significance in SCLCs & 185 \\
\hline MMP-11 & Adverse prognosis in SCLCs & 185 \\
\hline MMP-14 & Negative predictive value in SCLCs & 185 \\
\hline L-myc & Correlated with variant SCLC/ambiguous predictive value & $32,160,163$ \\
\hline Metallothionein & Adverse prognostic significance in SCLCs & 134 \\
\hline $\mathrm{N}-\mathrm{myc}$ & Correlated with variant SCLC/ambiguous predictive value & $32,169,163$ \\
\hline PAI-2 & Favorable prognostic value in NE tumors & 188 \\
\hline p53 & Arguable prognostic role in NE tumors & $60,126,133,134$ \\
\hline P-glycoprotein & Its expression has negative prognostic role in SCLCs & $255-257$ \\
\hline $\mathrm{pRb}$ & $\mathrm{LOH}$ is related to a poor clinical outcome in NE tumors & 49 \\
\hline Telomerase & Adverse prognostic significance in NE tumors & 183 \\
\hline TIMP-1 & Associated with better response to therapy & 185 \\
\hline Topo II $\alpha$ & Its elevation correlates with adverse prognosis in SCLCs & 121 \\
\hline VEGF & Related to chemoresistance and adverse prognosis in SCLCs & 206,207 \\
\hline
\end{tabular}

Abbreviations: SCLC, Small-cell lung cancer; NE, neuroendocrine; LOH, Loss of heterozygosity.

CD44 is a TM glycoprotein that belongs to the immunoglobulin superfamily, acting as an ECMbinding glycan as well as a hyaluronate receptor. It has a number of variant isoforms. These isoforms (CD44v1-v10) are the product of alternative splicing; the most abundant isoform is CD44 standard (CD44S) (99). CD44S levels decrease in SCLCs and ACs, whereas it is overexpressed in TCs (100). Loss of CD44v6 is associated with more aggressive types of SCLCs and ACs, although it is probably related with nodal metastasis in TCs (100). The CD44v10 variant is mainly expressed in SCLCs, correlating with the expression of characteristic proteins of tumor growth and progression (101).

CD99 is a TM glycoprotein encoded by $M I C 2$ located both on chromosomes $\mathrm{X}$ and $\mathrm{Y}$. It acts as an adhesion molecule, as well as a modulator of the action of IGF-I, insulin, and growth hormone. Its most common application is diagnosis and monitoring of Ewing's sarcoma/peripheral neuroectodermal tumor; however, its biological role still remains elusive (102). CD99 is detected in TCs, but it is not expressed in ACs or LCNECs (102-104).

Apoptosis (Programmed Cell Death) and Bcl-2 Family

Bcl-2 oncoprotein and the p53 TSG are prominent components of the pathways that regulate cellular apoptosis. Bcl-2 is a well-characterized inhibitor of programmed cell death, residing on the outer mitochondrial membrane, endoplasmic reticulum, and nuclear envelope. The family of apoptotic regulators also includes BCL-X $\mathrm{L}_{\mathrm{L}}, \mathrm{BCL}-\mathrm{X}_{\mathrm{S}}, \mathrm{Bax}, \mathrm{Bad}, \mathrm{Bak}, \mathrm{MCL}-1$ (myeloid cell leukemia-1), and other cellular and viral homologs (105). Specifically, Bax and Bak induce apoptosis $(106,107)$, and MCL-1 prevents cell death (108). Bax, a downstream transcriptional target of p53 (109), forms heterodimers with Bcl-2 in vivo (107) and this Bcl-2/Bax balance is important for progression toward apoptosis. MCL- 1 has also been shown to interact both with Bcl-2 and Bax (110,111).

The apoptotic index of SCLCs is low (112); the majority overexpress the $\mathrm{Bcl}-2$ protein, thus resisting the apoptotic process (112-120). Although increased levels of Bcl-2 have been described as correlating with a short life expectancy (121), other studies did not confirm this relationship (122). However, Bcl-2 presence may be important for the overall outcome of the patient; it can modulate the cytotoxicity of some anticancer drugs by inhibiting apoptosis (123). A possible mechanism for this effect is the inhibition of loss of the mitochondrial transmembrane potential and the prevention of the release of cytochrome $c$ (120). In contrast to SCLCs, carcinoids display low $B c l-2$ and augmented Bax expression levels $(23,112)$. 
The interesting observation, that in metastatic SCLCs both $B c l-2$ and $B a x$ expression are decreased, may be indicative of development of metastatic clones that are resistant to apoptosis (124).

Expression of $B c l-2, B a k$, and $M C L-1$ seems to relate to NE differentiation in large-cell lung carcinomas (LCLCs) (125). Interestingly, high apoptotic rates have been detected in LCNECs $(112,125)$. High apoptotic activity and low $\mathrm{Bcl}-2$ protein expression was correlated with poor prognosis in LCNECs (125). Perhaps this finding, which should be further investigated, reveals a condition that favors the development of apoptosis-resistant metastatic clones, similar to the case of metastatic SCLCs discussed above.

$B c l-2$ is more often expressed and the apoptotic indices are higher in ACs compared to TCs (100,113, $126,127)$, whereas $B C L-X$ is overexpressed in TCs (127). In a study by Laitinen et al. (126), MCL-1 and Bak were found to be highly expressed in carcinoid tumors, without, however, being associated with the apoptotic index, or Bax or Bcl-2 expression.

\section{Nuclear Factors}

The $p 53$ TSG, mapped to chromosome locus 17p13.1, participates in multiple cellular activities, such as G1 and G2 checkpoint control, maintenance of genomic integrity, DNA repair, replication, transcription, apoptosis, and differentiation $(128,129)$. Overexpression of $p 53$, as well as mutations, are mainly detected in high-grade NE neoplasms $(60,100)$. According to Przygodzki et al. (60), the role of p53 is to confront the important genetic alterations that are increasing in the spectrum of NE tumors, from TCs to SCLCs. p53 mutations are detected in the majority of SCLCs $(23,38,118,130-132)$ and are likely to be related with smoking and the carcinogens found in tobacco (23 and references therein). Allelic losses and/or mutations of $p 53$ seem to be correlated with poorer prognosis in NE lung tumors $(60,133)$, although some studies do not concur (134).

$17 p$ losses seem to be absent in TCs and rare in ACs $(11,58,60,112,127,135-138)$. Absence of p53 mutations in TCs might be responsible for their benign clinical course, and their presence in some ACs could explain their higher aggressiveness $(60,126)$.

p2 $7^{\mathrm{KIP} 1}$ protein is a cyclin-dependent kinase (CDK) inhibitor, acting as a negative regulator of the cell cycle. Interestingly, and in contrast to NSCLCs, expression of p27 is elevated in SCLCs in vivo (139). Our group has observed a similar situation in breast carcinomas, where increased p27 levels correlate with lymph node metastasis (140). This intriguing finding can be explained by the role of c-myc; as Vlach et al. (141) have shown that c-myc can induce sequestration of $\mathrm{p} 27$ in a form unable to bind the cyclin E/CDK2 complex. However, Masuda et al. (142) demonstrated that p27 inhibits cyclin E/CDK2 activity despite c-myc action. They further demonstrated that p27 protects SCLC cells from apoptosis in vivo, especially in conditions of hypoxia and low vascularity that usually accompany SCLC growth. Nevertheless, the possible mechanisms, which may bypass the cell-cycle inhibitory role of p27 and provide tumor-growth advantages, should be further studied.

The pl6-cyclin Dl/CDK4,6-Rb pathway is important in the regulation of the Gl/S transition and alterations in its various elements are implicated in lung carcinogenesis.

$\mathrm{pRb}$, the $105-\mathrm{kDa}$ product of the retinoblastoma $(R b)$ gene located on chromosome 13q14, is a key component of the cell-cycle regulatory machinery, which normally inhibits GI/S transition by sequestering the E2F-1 transcription factor. Alterations that deregulate $\mathrm{pRb}$ function are common among human malignancies, including NE tumors, with the most frequent being nonsense mutations, aberrant splicing events, and deletions (143-147). Loss of heterozygosity at $R b$ gene is significantly more frequent in SCLCs $(67 \%)$ than in NSCLCs $(31 \%)(23)$. Several studies showed that pRB expression was absent in high-grade NE tumors, whereas it was detected in TCs and ACs $(11,38,58,134,135,143-145$, 148-152). In only one study, loss of heterozygosity at $R b$ gene has been related to poor prognosis in all NE lung tumors (49).

E2F-1, a member of the E2F family of transcriptional modulators, plays a key regulatory role in cell-cycle progression, apoptosis, and differentiation (153). Eymin et al. (154) demonstrated that E2F-1 is overexpressed in both SCLCs and LCNECs and is accompanied by increased Ki-67 index (see below) and a Bcl-2:Bax ratio $>1$, suggesting a strong implication of E2F-1 deregulation in SCLC tumorigenesis. Interestingly, our group reached to a similar conclusion in NSCLCs (155).

The $p 16^{I N K 4 A}$ gene (also known as CDKN2, MTSI, or INK4a), located on chromosome $9 p 21$, is an inhibitor of CDK4,6 that controls cell-cycle progression by phosphorylating (thus inactivating) pRb (156). Homozygous alterations (i.e., deletions, point mutations, aberrant methylation) of this gene occur more frequently in NSCLCs than in SCLCs $(143,157)$. p16 aberrant methylation has been considered to be an early event in NSCL carcinogenesis. Additional studies are required to this direction concerning SCLCs and the SCLC-associated normal bronchial epithelium (23 and references therein). Yuan et al. (149) have demonstrated conserved pl6 expression in primary SCLCs that is, however, unable to regulate cell-cycle arrest, possibly due to the inactivation of $\mathrm{pRb}$. Interestingly, reintroduction of the $p 16$ gene in $p 16^{(-)}$SCLC tumors resulted in the suppression of tumor growth due to the expression of exogenous pl6 protein and the dephosphorylation (hence activation) of endogenous pRb (158).

p $15^{\mathrm{INK} 4 \mathrm{~B}}$ is a cell-cycle inhibitor that belongs to the INK4 family. The corresponding gene is located in the same region as $p 16^{I N K 4 A}$. It encodes two protein isoforms, p15 and p15.5, which are highly 
expressed in normal lung tissue. Chaussade et al. (159) showed a correlation in the expression of these two proteins in normal lung, which was not found in tumor-associated normal lung and tumors. Furthermore, they demonstrated increasing p15.5 levels from control lung samples to tumor-associated normal lung to low-grade NE tumors, suggesting a role in lung carcinogenesis that warrants further investigation.

Cyclin Dl is the best-characterized member of the Gl cyclin family. It is encoded by the CCND1 gene located on chromosome 11q13. The cyclin D1/CDK4,6 complex mediates the phosphorylation and functional inactivation of $\mathrm{pRb}$ promoting Gl/S transition (156). The absence of deregulated cyclin Dl expression (overexpression) in primary SCLCs $(23,149)$ and SCLC cell lines $(150)$ suggests that this molecule is probably not a major player in growthcontrol escape in SCLCs and that the mechanisms are different from those in NSCLCs, where cyclin DI is overexpressed.

The myc family of proto-oncogenes, comprising $c-m y c, L-m y c$, and $N-m y c$, has an essential role in the regulation of cell proliferation and differentiation. The role of each member in SCLC tumorigenesis has not yet been completely defined $(160,161)$; however, their amplification and/or overexpression is very frequent in SCLCs $(54,160,162)$. Notably, only one member of the myc family is overexpressed or amplified in one specific carcinoma or cell line (160). Altered expression of $c-m y c$ is often correlated with adverse prognosis in SCLCs $(160,163)$. The documented presence of myc amplification in metastatic lesions rather than primary tumors, in patients treated with chemotherapy, and in variant SCLCs suggest that it is a late event in the progression of these carcinomas $(163,164)$, explaining the correlation with poor prognosis. It has been reported that $c-m y c$ overexpression occurs in classic SCLC, whereas $L-m y c$ and $\mathrm{N}$-myc overexpression is likely to lead to the variant phenotype of SCLC, perhaps contributing to their characteristic radioresistance and aggressive course (32); however, other groups failed to confirm any prognostic value of $L-m y c$ or $N$-myc amplification or overexpression in SCLCs (160 and references therein, 163). Gains on $8 q$, the region harboring $c-m y c$, are frequently observed in SCLC and the newly incorporated material often encompasses the c-myc locus, indicating its involvement in the carcinogenetic process (165). Furthermore, c-myc may be implicated in drug resistance in SCLC cell lines, although the mechanism is not yet fully realized $(166,167)$.

CC3 is a highly conserved gene encoding a small protein (also known as TIP30) with metastasissuppressor properties for SCLC (168). CC3 expression is absent in the highly aggressive variant SCLCs, but it is detected in the less metastatic classic type of SCLCs, in other tumors, and in normal tissue (168). CC3 introduction in variant SCLCs results in metastatic suppression, that is at least partially due to activation of apoptosis (169). Furthermore, it has been demonstrated that CC3 is capable of inhibiting angiogenesis by inducing changes on several angiogenic modulators, ultimately influencing their metastatic potential (170).

c-raf- 1 is a serine/threonine protein kinase that participates in the mitogen-activated protein kinase/ extracellular signal-regulated kinase (MAPK/ERK) signal transduction pathways (171). Ravi et al. (172) have shown that an estradiol-regulated type of raf can prevent tumor growth in SCLC cells, through the blockage of neoplastic cells in G1 and G2 phases of the cell cycle. Interestingly, this arrest is accompanied by p27 induction. Activation of ras may recruit raf to the cell membrane, where it is potentiated via tyrosine phosphorylation $(173,174)$. Nevertheless, it should be noted that ras mutations are very rare in SCLCs $(60,66)$, and no mutations of $c$-raf have been detected in NE lung tumors (60), leaving the significance of raf an open issue.

The raf-MEK-MAPK pathway has been shown to relate with Notch signaling (175). Notch proteins play a critical role in nervous system development, by inhibiting basic helix-loop-helix transcription factors, such as hASHl (human achaete-scute homolog-1). As far as the SCLC cells are concerned, Notch proteins induce p2 1 and p27 as well as the ras pathway, whereas they down-regulate hASHl, resulting in cell-cycle arrest in Gl phase. The effect of Notch activation seems to be the suppression of SCLC growth (175). However, the Notch signaling pathway has to be further analyzed, not only in SCLCs but also in the rest of the NE lung tumors.

$c$-kit is a proto-oncogene encoding a tyrosine kinase receptor. Its ligand is the stem cell factor (SCF). The SCF/kit autocrine loop is functional in the majority of SCLCs and is a contributor to growthfactor independence of SCLC (176). Furthermore, SCF may act as a chemotactic factor for SCLC $(23,55)$. Interestingly, c-myc seems to be a direct or indirect modulator of $c$-kit expression in SCLC (176).

c-ets-1, a proto-oncogene encoding a transcription factor, modulates ECM-degrading protease gene expression during tumor invasion. It is considered to be involved in angiogenesis during wound healing in humans (177), and it was suggested that basic fibroblast growth factor (bFGF; see below) and tumor necrosis factor (TNF- $\alpha$ ) are possible candidates for inducing $c$-ets- 1 gene transcription in fibroblasts in vitro $(177,178)$. c-ets-1 is expressed in NE tumors of advanced stages-SCLCs and LCNECs-suggesting a potential role in tumor invasion (179).

\section{Enzymes}

Human telomeres consist of tandem repeats (TTAGGG), a number of which are lost by the end of each cell division cycle. The ribonucleoprotein telomerase is capable of synthesizing such telomeric sequences, thus protecting chromosomal ends from 
mitotic senescence (180). The fraction of cells possessing telomerase activity is approximately $100 \%$ in SCLCs (66). Telomerase levels are regarded as an indicator of the mortal-to-immortal cell ratio in a tumor. This leads to the conclusion that SCLCs mainly consist of immortal cells (181). It must be noted that telomerase activity is higher in extensive than in limited SCLCs (182). Besides, with the exception of TCs, all NE tumors display high telomerase expression, which seems to be associated with adverse prognosis (183).

Matrix metalloproteinases (MMPs) belong to a family of ECM-degrading enzymes, participating in tumor invasion, metastasis, and angiogenesis. To date, 16 MMPs have been identified, either in insoluble form or as TM proteins on the cell surface (184). The available information concerning SCLCs and generally NE tumors is very limited. Michael et al. (185) have observed elevated expression of MMP-3, MMP-11, and MMP-14 by SCLC cells, which was associated with adverse prognosis. The activities of MMPs are regulated by a class of proteins known as tissue inhibitors of MMPs (TIMPs) comprising TIMP-1, $-2,-3$, and -4 (184). TIMPs are widely expressed in SCLCs. However, only TIMP-1 underexpression in SCLCs was found to be statistically significant by multivariate analysis, being associated with better response to therapy (185).

The urokinase-type plasminogen activator (u-PA) is a serine protease that converts plasminogen into plasmin. This event leads to degradation of several components of the ECM. The plasminogen activator inhibitors PAI-1 and -2 control the activity of u-PA. Binding of u-PA to its receptor seems to enhance tumor-cell invasion. The u-PA system is implicated in the activation of several GFs, cell migration, and apoptosis (186). Expression of u-PA is correlated with aggressiveness in NE tumors $(187,188)$. In SCLC and LCNEC both stromal and epithelial u-PA expression are observed, and the stromal expression is related to lymph node metastasis; u-PA is not detectable in TCs (187). PAI-1 and -2 are inversely expressed in the spectrum of NE tumors, with PAI-1 being highly expressed in SCLCs and LCNECs and PAI-2 being more elevated in TCs, thus implying a favorable prognostic value of the latter. A possible mechanism for this is the synergic activity of PAI-1 with u-PA in high-grade NE tumors, in contrast to PAI-2, which probably prevents tumor progression via the blockade of u-PA-mediated proteolysis (188).

\section{Kinetic Parameters-Proliferation Markers}

A controversy exists on whether S-phase fraction has any prognostic value in SCLCs. Tinnemans et al. (189) have failed to confirm any prognostic significance in these carcinomas, probably due to the small cohort of patients in their study. Nevertheless, it must be noted that $S$-phase fraction differs in limited and extensive disease, probably reflecting the aggressiveness of the tumor (190).

Proliferating cell nuclear antigen (PCNA) is a 36-kDa non-histone nucleoprotein that binds to DNA polymerase and participates in DNA replication. Reaching its peak concentration during the $S$ phase, PCNA provides a useful tool for the identification of cycling cells (191). PCNA labeling index can be a diagnostic tool for distinguishing between TCs and ACs (135). However, its role as a prognostic marker is very limited in patients with SCLC (134).

The most reliable method for estimating the proliferating status is immunohistochemical analysis using the nuclear marker Ki-67, a monoclonal antibody assessing the growth fraction of human tumors (192). Increased proliferation rates have been suggested to associate with higher grade of $\mathrm{NE}$ lung tumors $(193,194)$. More specifically, SCLCs exhibit a high proliferative activity, which reflects their extremely fast growth (114). Increased proliferation is associated with poor survival in SCLCs and welldifferentiated NE carcinomas $(121,133,195)$. Finally, proliferation rates are more elevated in ACs than in TCs, implying a higher risk for patients with ACs $(11,126,127,135,196)$.

\section{Angiogenetic Factors and Angiogenesis}

Angiogenesis, the formation of new blood vessels, represents an essential process for tumor growth and metastasis (197). Angiogenesis, assessed by tumor microvessel density, does not bear any relation to the grade of NE tumors (194). Specifically, it cannot be characterized as an indicator of metastatic potential in carcinoids (198) and it is not associated with metastatic status, tumor size, or prognosis in SCLCs (199). However, the prognostic role of the inducers and inhibitors that control the angiogenetic process appears to be very promising.

Vascular endothelial growth factor (VEGF) is a potent inducer of angiogenesis that acts by forming heterodimeric complexes with two tyrosine kinase receptors: VEGF receptor 1 or Flt-1 (Fms-like tyrosine kinase), and VEGF receptor 2, also known as KDR/Flk-1 (kinase insert domain-containing receptor) $(200,201)$. VEGF has been shown to increase during lung cancer progression and this up-regulation is often associated with hypoxia $(202,203)$. VEGF is also able to up-regulate the expression of its receptors in ischemic conditions, contributing with a positive feedback to tumor angiogenesis $(203,204)$. Tissue VEGF protein expression was positively associated with vessel density in SCLC cell lines (205). Two reports have shown by multivariate analysis that high serum levels of VEGF are correlated with short life expectancy $(206,207)$. Specifically, Salven et al. (206) have suggested that increased levels of VEGF detected before chemotherapy are correlated with chemoresistance and, therefore, with adverse prognosis in SCLC patients. 
The FGF family members ally with heparin sulfate in the ECM, forming a reservoir of GFs that participate in development, hematopoiesis, angiogenesis, and wound repair (208). The best-characterized members are FGF-1 (acidic FGF) and FGF-2 (bFGF). bFGF was found to act synergistically with VEGF in vivo (209). Augmented tissue bFGF levels were not correlated with vessel density in SCLC xenografts (205). However, Ueno et al. (210) have recently demonstrated that increased serum bFGF levels not only associate with favorable prognosis of SCLC patients, but they are detected in those who respond to chemotherapy, suggesting that bFGF could act as a monitor marker in patients with SCLCs.

TSP-1 is an ECM protein regulating growth, motility, and adhesion of cells, which can act as an angiogenetic inhibitor. TSP-1 expression is regulated by p53 (211). As mentioned, TSP-1 induces $\alpha 3 \beta 1$ integrin adhesion and neurite-like differentiation, and it prevents proliferation of SCLC cells (74). Alterations of TSP-1 in SCLCs is a research area awaiting further exploration.

\section{Early and Late Molecular Events in Carcinogenesis of NE Tumors}

The progression of epithelial tumors is accompanied by multiple genetic events. The increasing incidence of these events during the preneoplastic stage is not random, but it is mediated via specific steps (212). Taking into account the progressive deterioration from TCs to SCLCs, NE tumors seem to represent a progressive clinical spectrum (26). However, in epidemiologic, pathologic, and molecular terms, TCs and SCLCs are distinct, unrelated entities $(27,213,214)$ and ACs and LCNECs do not appear to represent intermediate stages between them (214), which may be indicative of a different process followed in their development. SCLCs are not accompanied by specific preneoplastic changes, whereas carcinoids are associated with inflammatory lesions in the airway $(23,215)$.

Based on their profiles, it has been proposed that SCLCs may originate from either normal or hyperplastic epithelia, without passing through characteristic preneoplastic pathologic changes (Fig. 1) (51). The most characteristic early molecular events, occurring during the course of SCL carcinogenesis, are allele losses and microsatellite alterations. These aberrations, leading to inactivation of several growth-inhibitory pathways (216), are present both in normal bronchial epithelium associated with SCLC, as well as in hyperplasia and squamous metaplasia accompanying SCLCs (23). $3 p$ deletion is considered to take place in the early stages of SCLC $(41,67)$. p 53 mutation is also an early event $(132)$, which has also been detected in SCLC-associated bronchial epithelium (51). Inactivation of the $\mathrm{pRb}$ pathway, including defects of p16, is likely to precede that of p53 $(132,135)$, leading to disruption of the control between Gl to S phase (23). It has been found that allelic losses at 3p14-25 and 13q12-14, as well as $13 q 14$ and $17 p 13$ are, respectively, correlated. This finding possibly implies that simultaneous alterations of FHIT and $R b$, as well as $R b$ and $p 53$,

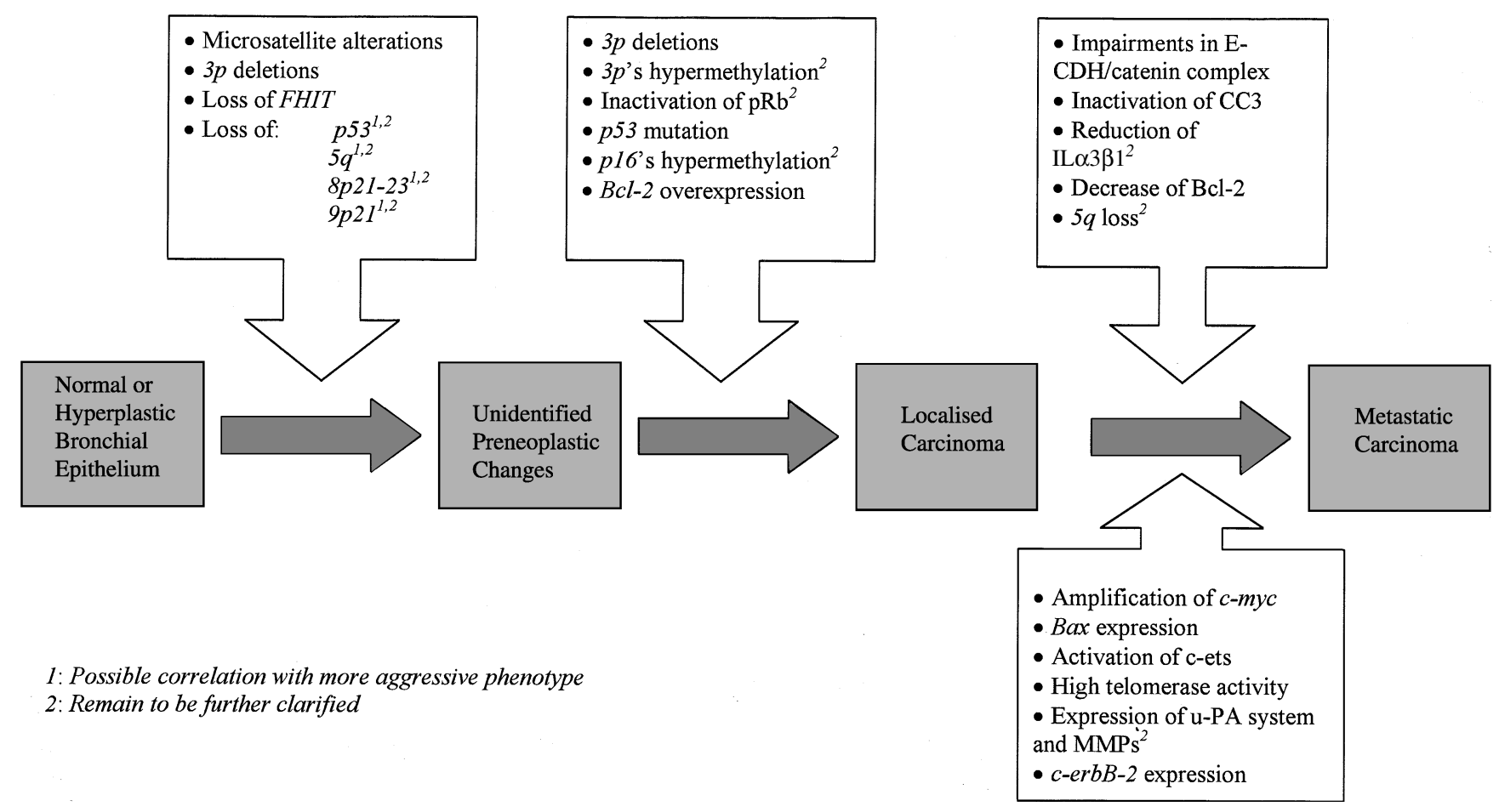

Fig. 1. Genetic events leading to SCLC. See text for details. 
which are located on the respective areas, are necessary for SCLC development (29). Furthermore, $3 p$ and $p 16$ are considered to be targets of aberrant methylation in SCLCs (23). Taking into account that hypermethylation is regarded as an early event in NSCL carcinogenesis, additional studies are needed to define its role in SCL carcinogenesis.

A number of molecular alterations are necessary for progression to the metastatic stage. Amplification of $c-m y c$ is considered to be a late event (36). This aberration is more frequently detected in SCLC cell lines derived from metastatic lesions than in primary tumors, in chemotherapy-treated patients, and in variant SCLCs (164). Overexpression of $c$-myc seems to down-regulate $\alpha 3 \beta 1$ integrin (91). Impairments in E-CDH/catenin complex have also been associated with tumor invasion and metastasis (93-95). Moreover, it should be noted that the observed gradual increase of $\mathrm{Bcl}-2$ in the clinical spectrum of NE tumors is not the case for metastatic SCLCs. In metastatic disease Bcl-2 is decreased, with a parallel decrease of Bax, which eventually leads to the attenuation of apoptosis. This may be attributed to the possible development of metastatic resistant-to-apoptosis clones (124). c-erbB-2 and c-ets expression have been associated with extensive disease in SCLCs (79), and it is likely that their expression may enhance tumor invasion $(178,179)$. Inactivation of $C C 3$ has been observed in the highly aggressive variant SCLCs; it is also expressed in the less metastatic classic type of SCLCs (168). Interestingly, telomerase activity becomes more apparent in extensive than in limited SCLCs (182). MMPs and the u-PA system promote tumor invasion in NE tumors, although additional studies are needed to clarify their role in these tumors $(184,187,188)$.

No specific genetic alteration is linked to metastatic carcinomas (34). One study implied that $5 q$ loss is a late event in SCLC carcinogenesis, being present in metastatic but not in primary SCLCs (53). However, Wistuba et al. (51) have detected this allelic loss, as well as loss at $8 p 21-23,9 p 21$, and $17 p 13$, in bronchial epithelium accompanying invasive SCLCs. It is possible that this early allelic loss can generate a very aggressive clone, which will metastasize. Specifically, the earlier some specific mutations occur, the more aggressive a SCLC tumor will become. The question arising from these observations is whether in case such alterations are detected in premalignant lesions the clinician should look out or expect metastasis. Further investigation is obviously required to address this issue.

\section{Ploidy}

Nuclear DNA content analysis has been assigned some prognostic significance in SCLC. Aneuploid tumors seem to carry a poorer prognosis, with this finding being independent of tumor stage (217). Furthermore, DNA content was proposed as an indicator of metastatic potential (218). However, other studies failed to confirm any prognostic value of the ploidy in SCLCs (190). Interestingly, Abe et al. (219) have observed that aneuploidy correlates with postoperative chemosensitivity of SCLC; the less aneuploid tumors are more chemoresistant. Kimura et al. (218), using tumor DNA content, demonstrated that peripheral SCLCs are more heterogeneous carcinomas than proximal SCLCs. The former are usually polyclonal and consequently more chemoresistant than the latter. ACs are more frequently aneuploid than TCs $(133,220)$. Aneuploidy in carcinoids has been assigned some prognostic significance $(220,221)$.

\section{Escape from Immune Surveillance in NE Lung Tumors}

Tumor cells develop a variety of immune surveillance escaping mechanisms. The antigen-major histocompatibility complex (MHC) class I complex pathway represents a frequent target in lung cancer (222). It includes (i) MHC class I, which is responsible for the presentation of foreign antigenic peptides to cytotoxic T-lymphocytes; (ii) $\beta 2$-microglobulin, which forms the light chain of class I molecules; (iii) LMP2 (latent membrane protein 2), which is a MHC-encoded proteasome subunit; and (iv) TAP (transporters associated with antigen presentation) (223). After degradation of cytoplasmic proteins in proteasome, TAP convey intracellular peptides into the endoplasmic reticulum, so that a complex with MHC class I is created. This complex formation leads to recognition by cytotoxic $\mathrm{T}$ lymphocytes (223). $\beta 2$-microglobulin has been suggested to be underexpressed in SCLC cell lines (224). Underexpression of TAP-1 and LMP2 genes has been observed in SCLC cell lines (224-226), providing a further explanation for the host immune surveillance escape. Interestingly, Singal et al. (226) have suggested that transfection of TAP genes may up-regulate MHC class I expression.

Host immune defense against lung cancer is reinforced by the presence of tumor-infiltrating lymphocytes (TILs). In human tumors, the majority are T cells. TILs secrete several cytokines that inhibit tumor progression, and it is through such mechanisms that the tumor-associated antitumor action of macrophages is regulated in lung cancer (227). Especially in SCLCs, $\mathrm{T}$ cells and macrophages are more abundant (199). It has been shown that a high proportion of intratumoral $\mathrm{T}$ cells, CD8 cells, and macrophages seem to improve prognosis in SCLCs $(199,228,229)$, particularly in cases of low-grade tumors (199).

Fas ligand (FasL) and its receptor Fas (also known as APO-1 or CD95) have a modulatory role in the apoptotic process of activated $\mathrm{T}$ cells (230). Niehans et al. (231) have shown that both SCLC and NSCLC human cell lines express FasL, suggesting that the FasL-Fas interaction may be a possible mechanism 
for the peripheral deletion of tumor-reactive T-cell clones observed in these tumors. Nevertheless, further studies examining the relationship between FasL expression and SCLC disease stage are needed.

The levels of the cytokines IFN- $\alpha$, IFN- $\gamma$, TNF- $\alpha$, and IL-2 are decreased in SCLCs (232). The factor behind this immunosuppressive effect seems to be TGF- $\beta 1$ (232). TNF- $\alpha$ is primarily produced by macrophages and monocytes (233). Its participation in pulmonary NE cell differentiation of SCLC cell lines has been suggested (234). Kayser et al. (235) have shown that TNF- $\alpha$-binding sites are expressed in $60-65 \%$ of SCLCs and their presence was correlated with intracellular presence of TNF protein. The significance of this finding should be further examined. TNF- $\beta$ is produced by lymphocytes (233). Its $10.5 / 10.5-\mathrm{kb}$ allele detection has been associated with favorable prognosis in patients with lung cancer (236). Decreased levels of IL-2 have been associated with adverse survival in SCLCs $(237,238)$. In addition, Sarandakou et al. (239) have shown that soluble IL-2 receptors are increased in this type of carcinoma and are correlated with poor prognosis, because IL-2 is unable to participate in cytotoxicity induced by lymphocytes.

The detection of p53 autoantibodies is widely examined as a possible predictive test for lung cancer. Zalcman et al. (240) have reported that p53 antibodies correlate with adverse prognosis in patients with limited stage SCLC. However, other studies have assigned no prognostic value to p53 autoantibodies in SCLCs (241-243). Perhaps the limited life expectancy in SCLCs does not permit the statistical evaluation of the impact of p53 autoantibodies on patient prognosis (241). On the other hand, Murray et al. (244) have recently shown that high levels of p53 antibodies correlate with favorable prognosis. Additional studies could aid in clarifying the role of p53 autoantibodies as a putative prognostic marker.

\section{Multidrug Resistance}

The shield of tumor cells against chemotherapy is multidrug resistance (MDR). The fundamental mechanisms of MDR are either decrease of cellular drug levels or prevention of drug-induced apoptosis (245).

Multidrug resistance-associated protein (MRP) is a TM 190-kDa glycoprotein, member of the ABC (ATP-binding cassette) superfamily. It functions as a TM transporter by keeping drug levels low via active efflux, thus offering MDR to tumor cells $(246,247)$. MRP is present in normal lung tissue and is expressed in SCLC tumor cells, being the main mechanism of MDR in these tumors (248). However, no correlation with chemotherapy response has been demonstrated (121). Besides MRP, the ABC family includes MRP-2, -3, -4, and -5, and among them MRP-3 seems to confer MDR in lung cancer cell lines (249).

P-glycoprotein, encoded by the MDRl gene, is another member of the ABC superfamily. Overexpression of P-glycoprotein causes active efflux of several drugs, leading to MDR (250). Interestingly, P-glycoprotein is rarely expressed in SCLCs $(148,251,252)$. However, Campling et al. (253) detected P-glycoprotein in clinical samples but not in SCLC cell lines, suggesting that it may be related to the clinically acquired MDR in SCLCs. In the same context, Kreisholt et al. (254) noticed an increase in P-glycoprotein in SCLC patients after treatment. Several studies demonstrated that increased P-glycoprotein levels are associated with bad prognosis (255-257). Finally, in carcinoid tumors a relatively high degree of $M D R 1$ expression has been reported (148), a finding that needs further confirmation.

Another mechanism of MDR, which leads to increased drug detoxification, is that of glutathione (GSH) conjugation and transport of glutathione-drug conjugates out of the cell. This system consists of GSH, GSH-related enzymes, and glutathione-conjugate export pump (GS-X pump). The export of GSH conjugates of anticancer drugs is accomplished either by GS-X pump or by MRP (258). Each factor of this system is capable of rising independently or in conjunction with the other factors of the system in SCLCs. For instance, increase of GSH has been observed in drug-resistant human SCLC lines, without any alteration in the levels of GSH-related enzymes, and increased GSH may be accompanied by elevated activity of GS-X pump in human lung cancer cells (258 and references therein). MDR SCLC cell lines display several alterations of GSH-related enzymes, whose significance is under investigation (259); as current data do not confirm a clear-cut role in drug response (260).

Topoisomerase II (Topo II) participates in DNA replication, transcription, and recombination (261). There are two subtypes of this enzyme: Topo II $\alpha$ $(170 \mathrm{kDa})$ and Topo II $\beta$ (180 kDa). Their expression is not correlated and this may be indicative of their different role in the progression of the cell cycle. Specifically, Topo II $\alpha$ is produced during cell division, and Topo II $\beta$ is expressed throughout the cell cycle, displaying higher levels in resting cells $(262,263)$. It has been demonstrated that the expression of Topo II $\alpha$ is higher in lung carcinomas than in normal lung tissue (263). Additionally, it is more elevated in SCLCs than NSCLCs $(254,263)$; Topo II $\beta$ levels exhibit no significant difference in these carcinomas (263). Topo II gene expression is associated with multidrug sensitivity, making it a possible chemosensitivity marker in lung cancer cell lines (264). Pretreatment Topo II $\alpha$ levels are considered to reflect chemosensitivity of SCLC to Topo II $\alpha$-targeting drugs, such as etoposide, better than MRP and P-glycoprotein do (254). Furthermore, increased levels of Topo II $\alpha$ correlate with adverse prognosis (121). Withoff et al. (265) have suggested that differential underexpression of Topo II $\alpha$ and Topo II $\beta$ may account for the chemoresistance in several SCLC cell lines. In pulmonary carcinoid 
tumors, Topo II $\alpha$ expression is more elevated in ACs than in TCs (266).

Metallothionein is a metal-binding protein rich in cysteine that has high affinity for $\mathrm{Cd}, \mathrm{Cu}$, and $\mathrm{Zn}$. It has been suggested to correlate with resistance to cisplatin (267). Joseph et al. (134) have shown by multivariate analysis that overexpression of metallothionein is associated with adverse prognosis in SCLC patients receiving chemotherapy.

\section{Conclusion-Outlook}

Progression of aggressiveness in NE tumors does not represent a common and gradual carcinogenetic process from low- to- high-grade tumors; different molecular pathways are altered in these histologic lesions. The evaluation of genetic and molecular factors, which are biochemically linked, permits the understanding of the different mechanisms implicated in the pathogenesis of these neoplasms. Among them, a variety of markers bearing a putative diagnostic and prognostic significance have been discussed. Meanwhile, further investigations are needed to confront MDR, which remains the dominant problem in treating SCLC patients. It is obvious that a successful management of NE tumors demands on one hand accurate techniques for monitoring their clinical, molecular, and immunologic status and, on the other hand, the introduction of unconventional therapeutic strategies. The accomplishment of this goal is certainly going to improve patient prognosis through treating each case individually.

\section{Acknowledgments}

We would like to thank Zoe Christoni for editorial assistance.

\section{References}

1. Minna JD. (1998) Neoplasms of the lung. In: Fauci A, Braunweld E, Isselbacher K, et al., eds. Harrison's Principles of Internal Medicine, 14th ed. New York: McGraw-Hill; pp. 552-562.

2. Travis WD, Colby TV, Corrin B, Shimosato Y, Brambilla E, in collaboration with Sobin LH, and pathologists from 14 countries. (1999) Histological typing of lung and pleural tumors. International Histological Classification of Tumors, 3rd ed. London, Springer, World Health Organization.

3. Capella C, Heitz PU, Hofler H, Solcia E, Kloppel G. (1995) Revised classification of neuroendocrine tumors of the lung, pancreas and gut. Virchows Arch. 425: 547-560.

4. Travis WD, Linnoila RI, Tsokos MG, et al. (1991) Neuroendocrine tumors of the lung with proposed criteria for large-cell neuroendocrine carcinoma: an ultrastructural, immunohistochemical, and flow cytometric study of 35 cases. Am. J. Surg. Pathol. 15: 529-553.

5. Junker K, Wiethege T, Muller KM. (2000) Pathology of small cell lung cancer. J. Cancer Res. Clin. Oncol. 126: 361-368.

6. Travis WD, Gal AG, Colby TV, Klimstra DS, Falk R, Ross MN. (1998) Reproducibility of neuroendocrine lung tumor classification. Hum. Pathol. 29: 272-279.

7. Brambilla E, Lantuejoul S, Sturm N. (2000) Divergent differentiation in neuroendocrine lung tumors. Semin. Diagnostic Pathol. 17: 138-148.
8. Dresler CM, Ritter JH, Patterson GA, Ross E, Bailey MS, Wick MR. (1997) Clinical-pathologic analysis of 40 patients with large cell neuroendocrine carcinoma of the lung. Ann. Thorac. Surg. 63: 180-185.

9. Travis WD, Rush W, Flieder DB, et al. (1998) Survival analysis of 200 pulmonary neuroendocrine tumors with clarification of criteria for atypical carcinoid and its separation from typical carcinoid. Am. J. Surg. Pathol. 22: 934-944.

10. Jiang SX, Kameya T, Shoji M, Dobashi Y, Shinada J, Yoshimura H. (1998) Large cell neuroendocrine carcinoma of the lung. A histologic and immunohistochemical study of 22 cases. Am. J. Surg. Pathol. 22: 526-537.

11. Rusch VW, Klimstra DS, Venkatraman ES. (1996) Molecular markers help characterize neuroendocrine lung tumors. Ann. Thorac. Surg. 62: 798-810.

12. Iyoda A, Hiroshima $\mathrm{K}$, Toyozaki T, Haga $\mathrm{Y}$, Fujisawa $\mathrm{T}$ Ohwada H. (2001) Clinical characterization of pulmonary large cell neuroendocrine carcinoma and large cell carcinoma with neuroendocrine morphology. Cancer 91: 1992-2000.

13. Heasley LE. (2001) Autocrine and paracrine signaling through neuropeptide receptors in human cancer. Oncogene 20: $1563-1569$.

14. Coulson JM, Fiskerstrand CE, Woll PJ, Quinn JP. (1999) Arginine vasopressin promoter regulation is mediated by a neuron-restrictive silencer element in small cell lung cancer. Cancer Res. 59: 5123-5127.

15. Coulson JM, Stanley J, Woll PJ. (1999) Tumor-specific arginine vasopressin promoter activation in small-cell lung cancer. Br. J. Cancer 80: 1935-1944.

16. Picon A, Leblond-Francillard M, Raffin-Sanson ML, Lenne F, Bertagna X, de Keyzer Y. (1995) Functional analysis of the human pro-opiomelanocortin promoter in the small-cell lung carcinoma cell line DMS-79. J. Mol. Endocrinol. 15: 187-194.

17. Davis TP, Crowell S, McInturff B, Louis R, Gillespie T. (1991) Neurotensin may function as a regulatory peptide in small cell lung cancer. Peptides 12: 17-23.

18. Geijer T, Folkesson R, Rehfeld JF, Monstein HJ. (1990) Expression of the cholecystokinin gene in a human (small cell) lung carcinoma cell line. FEBS Lett. 270: 30-32.

19. Khuder SA. (2001) Effect of cigarette smoking on major histological types of lung cancer: a meta-analysis. Lung Cancer 31: 139-148.

20. Barbone F, Bovenzi M, Cavallieri F, Stanta G. (1997) Cigarette smoking and histologic type of lung cancer in men. Chest 112: 1474-1479.

21. Khuder SA, Dayal HH, Mutgi AB, Willey JC, Dayal G. (1998) Effect of cigarette smoking on major histological types of lung cancer in men. Lung Cancer 22: 15-21.

22. Yang CP, Gallagher RP, Weiss NS, Band PR, Thomas DB, Russell DA. (1989) Differences in incidence rates of cancers of the respiratory tract by anatomic subsite and histologic type: an etiologic implication. J. Natl. Cancer Inst. 81: $1828-1831$.

23. Wistuba II, Gazdar AF, Minna JD. (2001) Molecular genetics of small cell lung carcinoma. Semin. Oncol. 28(suppl 4): 3-13.

24. Martini N, Zaman MB, Bains MS, et al. (1994) Treatment and prognosis in bronchial carcinoid involving regional lymph nodes. J. Thorac. Cardiovasc. Surg. 107: 1-7.

25. Janssen-Heijnen ML, Coebergh JW. (2001) Trends in incidence and prognosis of the histological subtypes of lung cancer in North America, Australia, New Zealand and Europe. Lung Cancer 31: 123-137.

26. Garcia-Yuste M, Matilla JM, Alvarez-Cago T, et al. (2000) Spanish Multicenter Study of neuroendocrine tumors of the lung of the Spanish Society of Pneumonology and Thoracic Surgery (EMETNE-SEPAR). Prognostic factors in neuroendocrine lung tumors: a Spanish multicenter study. Ann. Thorac. Surg. 70: 258-263.

27. Modlin IM, Sandor A. (1997) An analysis of 8305 cases of carcinoid tumors. Cancer 79: 813-829.

28. Ullmann R, Schwendel A, Klemen H, Wolf G, Petersen I, Popper HH. (1998) Unbalanced chromosomal aberrations in 
neuroendocrine lung tumors as detected by comparative genomic hybridization. Hum. Pathol. 29: 1145-1149.

29. Girard L, Zochbauer-Muller S, Virmani AK, Gazdar AF, Minna JD. (2000) Genome-wide allelotyping of lung cancer identifies new regions of allelic loss differences between small cell lung cancer and non-small cell lung cancer, and loci clustering. Cancer Res. 60: 4894-4906.

30. Petersen I, Langreck H, Wolf G, et al. (1997) Small-cell lung cancer is characterized by a high incidence of deletions on chromosomes 3p, 4q, 5q, 10q, 13q and 17p. Br. J. Cancer 75: 79-86.

31. Virmani AK, Fong KM, Kodagoda D, et al. (1998) Allelotyping demonstrates common and distinct patterns of chromosomal loss in human lung cancer types. Genes Chromosomes Cancer 21: 308-319.

32. Levin NA, Brzoska P, Gupta N, Minna JD, Gray JW, Christman MF. (1994) Identification of frequent novel genetic alterations in small cell lung carcinoma. Cancer Res. 54: 5086-5091.

33. Levin NA, Brzoska PM, Warnock ML, Gray JW, Christman MF. (1995) Identification of novel regions of altered DNA copy number in small cell lung tumors. Genes Chromosomes Cancer 13: 175-185.

34. Schwendel A, Langreck H, Reichel M, et al. (1997) Primary small-cell carcinomas and their metastases are characterised by a recurrent pattern of genetic alterations. Int. J. Cancer 74: 86-93.

35. Ried T, Petersen I, Holtgreve-Grez H, et al. (1994) Mapping of multiple DNA gains and losses in primary small cell lung carcinomas by comparative genomic hybridization. Cancer Res. 54: 1801-1806.

36. Testa JR, Liu Z, Feder M, et al. (1997) Advances in the analysis of chromosome alterations in human lung carcinomas. Cancer Genet. Cytogenet. 95: 20-32.

37. Ullmann R, Petzmann S, Sharma A, Cagle P, Popper H. (2001) Chromosomal aberrations in a series of large-cell neuroendocrine carcinomas: Unexpected divergence from small-cell carcinoma of the lung. Hum. Pathol. 32: 1059-1063.

38. Miura I, Graziano SL, Cheng JQ, Doyle A, Testa JR. (1992) Chromosome alterations in human small-cell lung cancer: frequent involvement of 5q. Cancer Res. 52: 1322-1328.

39. Michelland S, Gazzeri S, Brambilla E, Robert-Nicoud M. (1999) Comparison of chromosomal imbalances in neuroendocrine and non-small-cell lung carcinomas. Cancer Genet. Cytogenet. 114: 22-30.

40. Lui W, Tanenbaum D, Larsson C. (2001) High level amplification of 1p32-33 and 2p22-24 in small cell lung carcinomas. Int. J. Oncol. 19: 451-457.

41. Sozzi G, Veronese ML, Negrini M, et al. (1996) The FHIT gene at 3p14.2 is abnormal in lung cancer. Cell 85: 17-26.

42. Fong KM, Biesterveld EJ, Virmani A, et al. (1997) FHIT and FRA3B 3pl4.2 allele loss are common in lung cancer and preneoplastic bronchial lesions and are associated with cancer-related FHIT cDNA splicing aberrations. Cancer Res. 57: 2256-2267.

43. Sozzi G, Huebner K, Croce CM. (1998) FHIT in human cancer. Adv. Cancer Res. 74: 141-166.

44. Sozzi G, Tornielli S, Tagliabue E, et al. (1997) Absence of Fhit protein in primary lung tumors and cell lines with Fhit gene abnormalities. Cancer Res. 57: 5207-5212.

45. Kovatich A, Friedland DM, Druck T, et al. (1998) Molecular alterations to human chromosome $3 p$ loci in neuroendocrine lung tumors. Cancer 83: 1109-1117.

46. Burbee D, Forgacs E, Zochbauer-Muller S, et al. (2001) Epigenetic inactivation of RASSFIA in lung and breast cancers and malignant phenotype suppression. J. Natl. Cancer Inst. 93: 691-699.

47. Dammann R, Li C, Yoon JH, Chin PL, Bates S, Pfeifer GP. (2000) Epigenetic inactivation of a RAS association domain family protein from the lung tumor suppressor locus $3 p 21.3$. Nat. Genet. 25: 315-319.

48. Virmani AK, Rahti A, Zochbauer-Muller S, et al. (2000) Promoter methylation and silencing of the retinoic acid receptor beta gene in lung carcinomas. J. Natl. Cancer Inst. 92: 1303-1307.
49. Onuki N, Wistuba II, Travis WD, et al. (1999) Genetic changes in the spectrum of neuroendocrine lung tumors. Cancer 85: 600-607.

50. Dooley S, Wundrack I, Blin N, Welter C. (1995) Coexpression pattern of c-myc associated genes in a small cell lung cancer cell line with high steady state c-myc transcription. Biochem. Biophys. Res. Commun. 13: 789-795.

51. Wistuba II, Berry J, Behrens C, et al. (2000) Molecular changes in the bronchial epithelium of patients with small cell lung cancer. Clin. Cancer Res. 6: 2604-2610.

52. D'Amico D, Carbone DP, Johnson BE, Meltzer SJ, Minna JD. (1992) Polymorphic sites within the MCC and APC loci reveal very frequent loss of heterozygosity in human small cell lung cancer. Cancer Res. 52: 1996-1999.

53. Hosoe S, Ueno K, Shigedo Y, et al. (1994) A frequent deletion of chromosome $5 \mathrm{q} 21$ in advanced small-cell and nonsmall-cell carcinoma of the lung. Cancer Res. 54: 1787-1790.

54. Giaccone G. (1996) Oncogenes and antioncogenes in lung tumorigenesis. Chest 109: 130S-134S.

55. Sekido Y, Takahashi T, Ueda R, et al. (1993) Recombinant human stem cell factor mediates chemotaxis of small cell lung cancer cell lines aberrantly expressing the c-kit protooncogene. Cancer Res. 53: 1709-1714.

56. Shivapurkar N, Virmani AK, Wistuba II, et al. (1999) Deletions of chromosome 4 at multiple sites are frequent in malignant mesothelioma and small cell lung carcinoma. Clin. Cancer Res. 5: 17-23.

57. Merlo A, Gabrielson E, Mabry M, Vollmer R, Baylin SB, Sidransky D. (1994) Homozygous deletion on chromosome $9 p$ and loss of heterozygosity on $9 q, 6 p$ and $6 q$ in primary human small cell lung cancer. Cancer Res. 54: 2322-2326.

58. Walch AK, Zitzelsberger HF, Aubele MM et al. (1998) Typical and atypical carcinoid tumors of the lung are characterised by liq deletions as detected by comparative genomic hybridization. Am. J. Pathol. 153: 1089-1098.

59. Debelenko LV, Swalwell JI, Kelley MJ, et al. (2000) MENI gene mutation analysis of high-grade neuroendocrine lung carcinoma. Genes Chromosomes Cancer 28: 58-65.

60. Przygodzki RM, Finkelstein SD, Langer JC, et al. (1996) Analysis of p53, K-ras-2, and C-raf- 1 in pulmonary neuroendocrine tumors. Am. J. Pathol. 148: 1531-1541.

61. Ullmann R Petzmann S, Klemen H, Fraire AE, Hasleton P, Popper HH. (2002) The position of pulmonary carcinoids within the spectrum of neuroendocrine tumors of the lung and other tissues. Genes Chromosomes Cancer 34: 78-85.

62. Jakobovitz O, Nass D, DeMarco L, et al. (1996) Carcinoid tumors frequently display genetic abnormalities involving chromosome 11. J. Clin. Endocrinol. Metab. 81: 3164-3167.

63. Dong Q, Debelenko LV, Chandrasekharappa SC, et al. (1997) Loss of heterozygosity at $11 \mathrm{ql} 3$ analysis of pituitary tumors, lung carcinoids, lipomas, and other uncommon tumors in subjects with familial multiple endocrine neoplasia type 1. J. Clin. Endocrinol. Metab. 82: 1416-1420.

64. Debelenko LV, Brambilla E, Agarwal SK, et al. (1997) Identification of MEN1 gene mutations in sporadic carcinoid tumors of the lung. Hum. Mol. Genet. 13: 2285-2290.

65. Petzmann S, Ullmann R, Klemen H, Renner H, Popper HH. (2001) Loss of heterozygosity on chromosome arm 11q in lung carcinoids. Hum. Pathol. 32: 333-338.

66. Sekido Y, Fong KM, Minna JD. (1998) Progress in understanding the molecular pathogenesis of human lung cancer. Biochim. Biophys. Acta 1378: F2 1-F59.

67. Hurr K, Kemp B, Silver SA, El-Naggar AK. (1996) Microsatellite alteration at chromosome $3 p$ loci in neuroendocrine and non-neuroendocrine lung tumors. Histogenetic and clinical relevance. Am. J. Pathol. 149: 613-620.

68. Merlo A, Mabry M, Gabrielson E, Vollmer R, Baylin S, Sidransky D. (1994) Frequent microsatellite instability in primary small cell lung cancer. Cancer Res. 54: 2098-2101.

69. Mao L, Lee DJ, Tockman MS, Erozan YS, Askin F, Sindransky D. (1994) Microsatellite alterations as clonal markers for the detection of human cancer. Proc. Natl. Acad. Sci. U. S. A. 91: 9871-9875. 
70. Chen XQ, Stroun M, Magnenat JL, et al. (1996) Microsatellite alterations in plasma DNA of small cell lung cancer patients. Nat. Med. 2: 1033-1035.

71. Gonzalez R, Silva JM, Sanchez A, et al. (2000) Microsatellite alterations and TP53 mutations in plasma DNA of small-cell lung cancer patients: follow-up study and prognostic significance. Ann. Oncol. 11: 1097-1 104.

72. Prigent SA, Lemoine NR. (1992) The type I (EGFR-related) family of growth factors receptors and their ligants. Prog. Growth Factor Res. 4: 1-24.

73. Genersch E, Schuppan D, Lichtner RB. (1996) Signaling by epidermal growth factor differentially affects integrinmediated adhesion of tumor cells to extracellular matrix proteins. J. Mol. Med. 74: 609-616.

74. Guo N, Templeton NS, Al-Barazi H, et al. (2000) Thrombospondin-1 promotes $\alpha 3 \beta 1$ integrin-mediated adhesion and neurite-like outgrowth and inhibits proliferation of small cell lung carcinoma cells. Cancer Res. 60: 457-466.

75. Gullick WJ. (1998) Type I growth factor receptors: current status and future work. Biochem. Soc. Symp. 63: 193-198.

76. Kaseda S, Ueda M, Ozawa S, Ishihara T, Abe O, Shimizu N. (1989) Expression of epidermal growth factor receptors in four histologic types of lung cancer. J. Surg. Oncol. 42: 16-20.

77. Damstrup L, Rygaard K, Spang-Thomsen M, Poulsen HS. (1992) Expression of the epidermal growth factor receptor in human small cell lung cancer cell lines. Cancer Res. 52: 3089-3093.

78. Haeder M, Rotsch M, Bepler G, et al. (1988) Epidermal growth factor receptor expression in human lung cancer cell lines. Cancer Res. 48: 1132-1136.

79. Micke P, Hengstler JG, Ros R, et al. (2001) c-erbB-2 expression in small-cell lung cancer is associated with poor prognosis. Int. J. Cancer 92: 474-479.

80. Jones J, Clemmons D. (1995) Insulin-like growth factors and their binding proteins: biological actions. Endocrinol. Rev. 16: 3-34.

81. Grimberg A, Cohen P. (2000) Role of insulin-like growth factors and their binding proteins in growth control and carcinogenesis. J. Cell Physiol. 183: 1-9.

82. Nakanishi Y, Mulshine J, Kasprzyc PG, et al. (1988) Insulinlike growth factor-I can mediate autocrine proliferation of human small cell lung cancer cell lines in vitro. J. Clin. Invest. 82: 354-359.

83. Hynes RO. (1992) Integrins: versatility, modulation, and signaling in cell adhesion. Cell 69: 11-25.

84. Feldman LE, Shin KC, Natale RB, Todd TG. (1991) $\beta 1$ integrin expression on human small cell lung cancer cells. Cancer Res. 51: 1065-1070.

85. Mette SA, Pilewski J, Buck CA, Albelda SM. (1993) Distribution of integrin cell adhesion receptors on normal bronchial epithelial cells and lung cancer cells in vitro and in vivo. Am. J. Respir. Cell Mol. Biol. 8: 562-572.

86. Bartolazzi A, Cerboni C, Flamini G, Bigotti A, Lauriola L, Natali PG. (1995) Expression of $\alpha 3 \beta 1$ integrin receptor and its ligands in human lung tumors. Int. J. Cancer 64: 248-252.

87. Pellegrini R, Martignone S, Menard S, Colnaghi MI. (1994) Laminin receptor expression and function in small-cell lung carcinoma. Int. J. Cancer 8(suppl): 116-120.

88. Hemler ME, Elices MJ, Chan BMC, Zetter B, Matsuura N, Takada Y. (1990) Multiple ligand binding functions for VLA-2 $\left(\alpha^{2} \beta 1\right)$ and VLA-3 $\left(\alpha^{3} \beta 1\right)$ in the integrin family. Cell Differ. Dev. 32: 229-238.

89. Elices MJ, Urry LA, Hemler ME. (1991) Receptor functions for the integrin VLA-3: fibronectin, collagen, and laminin binding are differentially influenced by ARGGLY-ASP peptide and by divalent cations. J. Cell. Biol. 112: 169-181.

90. Virtanen I, Laitinen A, Tani T, et al. (1996) Differential expression of laminins and their integrin receptors in developing and adult human lung. Am. J. Respir. Cell. Mol. Biol. 15: 184-196.

91. Barr LF, Campbell SE, Bochner BS, Dang CV. (1998) Association of the decreased expression of $\alpha 3 \beta 1$ integrin with the altered cell: environmental interactions and enhanced soft agar cloning ability of c-myc-overexpressing small cell lung cancer cells. Cancer Res. 58: 5537-5545.

92. Tokman MG, Porter RA, Williams CL. (1997) Regulation of cadherin-mediated adhesion by the small GTP-binding protein Rho in small cell lung carcinoma cells. Cancer Res. 57: 1785-1793.

93. Jankowski JA, Bruton R, Shepherd N, Sanders DC. (1997) Cadherin and catenin biology represent a global mechanism for epithelial cancer progression. Mol. Pathol. 50: 289-290.

94. Shiozaki H, Oka H, Inoue M, Tamura S, Monden M. (1996) E-cadherin mediated adhesion system in cancer cells. Cancer 77(suppl): 1605-1613.

95. Clavel CE, Nollet F, Berx G, et al. (2001) Expression of the E-cadherin-catenin complex in lung neuroendocrine tumors. J. Pathol. 194: 20-26.

96. Tsukita S, Tsukita S, Nagafuchi A, Yonemura S. (1992) Molecular linkage between cadherins and actin filaments in cell-cell adherens junctions. Curr. Opin. Cell Biol. 4: 834-839.

97. Nishimura M, Machida K, Imaizumi M, et al. (1996) Tyrosine phosphorylation of 100-130 kDa proteins in lung cancer correlates with poor prognosis. Br. J. Cancer 74: 780-787.

98. Rodriguez-Salas N, Palacios J, de Castro J, Moreno G, Gonzalez-Baron M, Gamallo C. (2001) Beta-catenin expression pattern in small-cell lung cancer: correlation with clinical and evolutive features. Histol. Histopathol. 16: 353-358.

99. Sneath RJ, Mangham DC. (1998) The normal structure and function of CD44 and its role in neoplasia. Mol. Pathol. 51: 191-200.

100. Coppola D, Clarke M, Landreneau R, Weyant RJ, Cooper D, Yousem SA. (1996) Bcl-2, p53, CD44 and CD44v6 isoform expression in neuroendocrine tumors of the lung. Mod. Pathol. 9: 484-490.

101. Mizera-Nyszac E, Dyszkiewicz W, Heider KH, Zeromski J. (2001) Isoform expression of CD44 adhesion molecules, Bcl-2, p53 and Ki-67 proteins in lung cancer. Tumor Biol. 22: $45-53$.

102. Stevenson AJ, Chatten J, Bertoni F, Miettinen M. (1994) CD99 (p30/32MIC2) neuroectodermal/Ewing's sarcoma antigen as an immunohistochemical marker. Review of more than 600 tumors and the literature experience. Appl. Immunohistochem. 2: 231-240.

103. Pelosi G, Fraggetta F, Sonzogni A, Fazio N, Cavallon A, Viale G. (2000) CD99 immunoreactivity in gastrointestinal and pulmonary neuroendocrine tumors. Virchows Arch. 437: 270-274.

104. Lumadue JA, Askin FB, Perlman EJ. (1994) MIC2 analysis of small cell carcinoma. Am. J. Clin. Pathol. 102: 692-694.

105. Strasser A, Huang DCS, Vaux DL. (1997) The role of the bcl2/ced-9 gene family in cancer and general implications of defects in cell death control for tumorigenesis and resistance to chemotherapy. Biochim. Biophys. Acta 1333: F151-F178.

106. Klefer MC, Brauer MJ, Powers VC, et al. (1995) Modulation of apoptosis by the widely distributed Bcl-2 homologue Bak. Nature 374: 736-739.

107. Oltvai ZN, Milliman CL, Korsmayer SJ. (1993) Bcl-2 heterodimerizes in vivo with a conserved homolog, Bax, that accelerates programmed cell death. Cell 74: 609-619.

108. Kozopas KM, Yang T, Buchan HI, Zhou P, Craig RW. (1993) Mcl-1, a gene expressed in programmed myeloid cell differentiation, has sequence similarity to Bcl-2. Proc. Natl. Acad. Sci. U. S. A. 90: 3516-3520.

109. Yin C, Knudson CM, Korsmeyer SJ, Van Dyke T. (1997) Bax suppresses tumorigenesis and stimulates apoptosis in vivo. Nature 385: 637-640.

110. Sato T, Hanada M, Bodrug S, et al. (1994) Interactions among members of the bcl-2 protein family analyzed with a yeast two-hybrid system. Proc. Natl. Acad. Sci. U. S. A. 91: 9238-9242.

111. Sedlak TW, Oltvai ZN, Yang E, et al. (1995) Multiple Bcl-2 family members demonstrate selective dimerizations with Bax. Proc. Natl. Acad. Sci. U. S. A. 92: 7834-7838. 
112. Brambilla E, Negoescu A, Gazzeri S, et al. (1996) Apoptosisrelated factors $\mathrm{p} 53, \mathrm{Bcl}-2$, and bax in neuroendocrine lung tumors. Am. J. Pathol. 149: 1941-1952.

113. Wang DG, Johnston CF, Sloan JM, Buchanan KD. (1998) Expression of Bcl-2 in lung neuroendocrine tumors: comparison with p53. J. Pathol. 184: 247-251.

114. Eerola AK, Tormanen U, Rainio P, et al. (1997) Apoptosis in operated small cell lung carcinoma is inversely related to tumor necrosis and p53 immunoreactivity. J. Pathol. 181: 172-177.

115. Jiang S, Sato Y, Kuwao S, Kameya T. (1995) Expression of bcl-2 oncogene protein is prevalent in small cell lung carcinomas. J. Pathol. 177: 135-138.

116. Ikegaki N, Katsumata M, Minna J, Tsujimoto Y. (1994) Expression of bcl-2 in small cell lung carcinoma cells. Cancer Res. 54: 6-8.

117. Ben-Ezra J, Kornstein M, Grimes M, Krystal G. (1994) Small cell carcinomas of the lung express the bcl-2 protein. Am. J. Pathol. 145: 1036-1040.

118. Stefanaki K, Rontogiannis D, Vamvouka C, et al. (1998) Immunohistochemical detection of bcl-2, p53, mdm2 and p21/wafl proteins in small-cell lung carcinomas. Anticancer Res. 18: 1689-1696.

119. Higashiyama M, Doi O, Kodama K, Yokouchi H, Tateishi R. (1995) High prevalence of bcl-2 oncoprotein expression in small cell lung cancer. Anticancer Res. 15: 503-505.

120. Sartorius UA, Krammer PH. (2002) Upregulation of Bcl-2 is involved in the mediation of chemotherapy resistance in human small cell lung cancer cell lines. Int. J. Cancer 97: 584-592.

121. Dingemans A, Witlox M, Stallaert R, Van der Valk P, Postmus P, Giaccone G. (1999) Expression of DNA topoisomerase II $\alpha$ and topoisomerase $\mathrm{II} \beta$ genes predicts survival and response to chemotherapy in patients with small cell lung cancer. Clin. Cancer Res. 5: 2048-2058.

122. Maitra A, Amirkhan R, Saboorian H, Frawley W, Ashfaq R. (1999) Survival in small cell lung carcinoma is independent of bcl-2 expression. Hum. Pathol. 30: 712-717.

123. Ohmori T, Rodack ER, Nishio K, et al. (1993) Apoptosis of lung cancer cells caused by some anti-cancer agents (MMC, CPT-11, ADM) is inhibited by bcl-2. Biochem. Biophys. Res. Commun. 192: 30-36.

124. Pal'tsev MA, Demura SA, Kogan EA, Jaques G, Zende B. (2000) Role of Bcl-2, Bax, and Bak in spontaneous apoptosis and proliferation in neuroendocrine lung tumors: immunohistochemical study. Bull. Exp. Biol. Med. 130: 697-700.

125. Eerola AK, Ruokolainen H, Soini Y, Raunio H, Paakko P. (1999) Accelerating apoptosis and low bcl-2 expression associated with neuroendocrine differentiation predict shortened survival in operated large cell carcinoma of the lung. Pathol. Oncol. Res. 5: 179-186.

126. Laitinen KLJ, Soini Y, Mattila J, Paakko P. (2000) Atypical bronchopulmonary carcinoids show a tendency toward increased apoptotic and proliferative activity. Cancer 88: 1590-1598.

127. Zirbes TK, Lorenzen J, Baldus SE, et al. (1998) Apoptosis and expression of bcl-2 protein are inverse factors influencing tumor cell turnover in primary carcinoid tumors of the lung. Histopathology 33: 123-128.

128. Prives C, Hall PA. (1999) The p53 pathway. J. Pathol. 187: 112-126.

129. Oren M, Prives C. (1996) p53: upstream, downstream and offstream. Review of the $8^{\text {th }}$ p53 workshop (Dundee, July 5-9, 1996). Biochim. Biophys. Acta 1288: R 13-R 19.

130. Gazdar AF. (1994) The molecular and cellular basis of human lung cancer. Anticancer Res. 13: 261-268.

131. D'Amico D, Carbone D, Mitsudomi T, et al. (1992) High frequency of somatically acquired p53 mutations in small-cell lung cancer cell lines and tumors. Oncogene 7: 339-346.

132. Sameshina Y, Matsuno Y, Hirohashi S, et al. (1992) Alterations of p53 gene are common and critical events for the maintenance of malignant phenotypes in small-cell lung carcinoma. Oncogene 7: 45 1-457.
133. Santinelli A, Ranaldi R, Bacarrini M, Mannello B, Bearzi I. (1999) Ploidy, proliferative activity, p53 and bcl-2 expression in bronchopulmonary carcinoids: relationship with prognosis. Pathol. Res. Pract. 195: 467-474.

134. Joseph M, Banerjee D, Kocha W, Feld R, Stitt L, Cherian M. (2001) Metallothionein expression in patients with small cell carcinoma of the lung. Cancer 92: 836-842.

135. Barbareschi M, Girlando S, Mauri Fa, et al. (1992) Tumor suppressor gene products, proliferation and differentiation markers in lung neuroendocrine neoplasms. J. Pathol. 166: 343-350.

136. Wang DG, Johnston CF, Anderson N, Sloan JM, Buchanan KD. (1995) Overexpression of the tumor suppressor gene p53 is not implicated in neuroendocrine tumor carcinogenesis. J. Pathol. 175: 397-401.

137. Iggo R, Gatter K, Bartek J, Lane D, Harris AL. (1990) Increased expression of mutant forms of $\mathrm{p} 53$ oncogene in primary lung cancer. Lancet 335: 675-679.

138. Lohmann DR, Fesseler B, Putz B, et al. (1993) Infrequent mutations of the p53 gene in pulmonary carcinoid tumors. Cancer Res. 53: 5797-5801.

139. Yatabe Y, Masuda A, Koshikawa T, et al. (1998) $\mathrm{p} 27^{\mathrm{KIP} 1}$ in human lung cancers: Differential changes in small cell and non-small cell carcinomas. Cancer Res. 58: 1042-1047.

140. Kouvaraki M, Gorgoulis VG, Rassidakis GZ, et al. (2002) High expression levels of p27 correlate with lymph node status in a subset of advanced invasive breast carcinomas. Relation to E-Cadherin alterations, proliferative activity, and ploidy of the tumors. Cancer 94: 2454-2465.

141. Vlach J, Henneckke S, Alevizopoulos K, Conti D, Amati B. (1996) Growth arrest by the cyclin-dependent kinase inhibitor $\mathrm{p} 27^{\mathrm{KIP} 1}$ is abrogated by c-myc. EMBO J. 15: 6595-6604.

142. Masuda A, Osada H, Yatabe Y, et al. (2001) Protective function of p2 $27^{\mathrm{KIP} 1}$ against apoptosis in small cell lung cancer cells in unfavorable microenviroments. Am. J. Pathol. 158 87-96.

143. Kelley MJ, Nakagawa K, Steinberg SM, Mulshine JL, Kamb A, Johnson BE. (1995) Differential inactivation of CDKN2 and $\mathrm{Rb}$ protein in non-small-cell and small-cell lung cancer cell lines. J. Natl. Cancer Inst. 87: 756-761.

144. Gouyer V, Gazzeri S, Bolon I, Drevet C, Brambilla C, Brambilla E. (1998) Mechanism of retinoblastoma gene inactivation in the spectrum of neuroendocrine lung tumors. Am. J. Respir. Cell. Mol. Biol. 18: 188-196.

145. Gouyer V, Gazzeri S, Brambilla E, et al. (1994) Loss of heterozygosity at the $\mathrm{Rb}$ locus correlates with loss of $\mathrm{RB}$ protein in primary malignant neuroendocrine lung carcinomas. Int. J. Cancer 58: 818-824.

146. Mori N, Yokota J, Akiyama T, et al. (1990) Variable mutations of the $\mathrm{Rb}$ gene in small-cell carcinoma. Oncogene 5: 1713-1717.

147. Grana X, Garigga J, Mayol X. (1998) Role of retinoblastoma protein family, pRB, p107 and p130 in the negative control of cell growth. Oncogene 17: 3365-3383.

148. Lai SL, Brauch H, Knutsen T, et al. (1995) Molecular genetic characterization of neuroendocrine lung cancer cell lines. Anticancer Res. 15: 225-232.

149. Yuan J, Knorr J, Altmannsberger M, et al. (1999) Expression of p16 and lack of pRb in primary small cell lung cancer. $J$. Pathol. 189: 358-362.

150. Schauer IE, Siriwardana S, Langen TA, Sclafani RA. (1994) Cyclin Dl overexpression vs retinoblastoma inactivation: implications for growth control evasion in non-small cell and small cell lung cancer. Proc. Natl. Acad. Sci. U. S. A. 91: 7827-7831.

151. Dosaka-Akita H, Cagle PT, Hiroumi H, et al. (2000) Differential retinoblastoma and $\mathrm{p} 16^{\mathrm{INK} 4 \mathrm{~A}}$ protein expression in neuroendocrine tumors of the lung. Cancer 88: 550-556.

152. Cagle PT, El-Naggar AK, Xu H, Hu S, Benedict WF. (1997) Differential retinoblastoma protein expression in neuroendocrine tumors of the lung. Am. J. Pathol. 150: 393-400.

153. Johnson DG, Schneider-Broussard R. (1998) Role of E2F in cell cycle control and cancer. Front. Biosci. 3: 447-448. 
154. Eymin B, Gazzeri S, Brambilla C, Brambilla E. (2001) Distinct pattern of E2F1 expression in human lung tumors: E2F1 is upregulated in small-cell lung carcinoma. Oncogene 20: 1678-1687.

155. Gorgoulis VG, Zacharatos P, Mariatos G, et al. (2002) Transcription factor E2F-1 acts as a growth-promoting factor and is associated with adverse prognosis in non-small cell lung carcinomas. J. Pathol. 194: in press.

156. Cordon-Cardo C. (1995) Mutation of cell-cycle regulators. Biological and clinical implications for human neoplasia (review). Am. J. Pathol. 147: 545-560.

157. Olopade OI, Buchhagen DL, Malik K, et al. (1993) Homozygous loss of the interferon genes defines the critical region on 9p that is deleted in lung cancers. Cancer Res. 53(suppl 10): $2410-2415$.

158. Sumitomo K, Shimizu E, Shinohara A, Yokota J, Sone S. (1999) Activation of Rb tumor suppressor protein and growth suppression of small cell lung carcinoma cells by reintroduction of pl6INK4A gene. Int. J. Oncol. 14: 1075-1080.

159. Chaussade L, Eymin B, Brambilla E, Gazzeri S. (2001) Expression of p15 and p15.5 products in neuroendocrine lung tumors: relationship with p $15^{\mathrm{INK} 4 \mathrm{~b}}$ methylation status. Oncogene 20: 6587-6596.

160. Prins J, De Vries E, Mulder N. (1993) The myc family of oncogenes and their presense and importance in small-cell lung carcinoma and other tumor types. Anticancer Res. 13: $1373-1386$.

161. Field JK, Spandidos DA. (1990) The role of ras and myc oncogenes in human solid tumors and their relevance in diagnosis and prognosis. Anticancer Res. 10: 1-22.

162. Rygaard K, Vindelov L, Spang-Thomsen M. (1993) Expression of myc family oncoproteins in small-cell lung-cancer cell lines and xenografts. Int. J. Cancer 54: 144-152.

163. Noguchi M, Hirohashi S, Hara F, et al. (1990) Heterogenous amplification of myc family oncogenes in small cell lung carcinoma. Cancer 66: 2053-2058.

164. Johnson BE, Russell E, Simmons AM, et al. (1996) Myc family DNA amplification in 126 tumor cell lines from patients with small cell lung cancer. J. Cell. Biochem. 24(suppl): 210-217.

165. Yamada T, Kohno T, Navarro JM, Ohwada S, Perucho M, Yokota J. (2000) Frequent chromosome 8q gains in human small-cell lung carcinoma detected by arbitrarily primed-PCR genomic fingerprinting. Cancer Genet. Cytogenet. 120: 11-17.

166. Van Waardenburg RCAM, Meijer C, Burger H, et al. (1997) Effects of an inducible anti-sense c-myc gene transfer in a drug-resistant human small-cell-lung-carcinoma cell line. Int. J. Cancer 73: 544-550.

167. Van Waardenburg RCAM, Prins J, Meijer C, Uges DRA, De Vries EGE, Mulder NH. (1996) Effects of c-myc oncogene modulation on drug resistance in human small cell lung carcinoma cell lines. Anticancer Res. 16: 1963-1970.

168. Shtivelman E. (1997) A link between metastasis and resistance to apoptosis of variant small-cell lung carcinoma. Oncogene 14: 2167-2173.

169. Xiao H, Palhan V, Yang Y, Roeder RG. (2000) TIP30 has an intrinsic kinase activity required for up-regulation of a subset of apoptotic genes. EMBO J. 19: 956-963.

170. NicAmhlaoibh R, Shtivelman E. (2001) Metastasis suppressor CC3 inhibits angiogenic properties of tumor cells in vitro. Oncogene 20: 270-275.

171. Seger R, Krebs EG. (1995) The MAPK signaling cascade. FASEB J. 9: 726-735.

172. Ravi RK, Weber E, McMahon M, et al. (1998) Activated Raf-1 causes growth arrest in human small cell lung cancer cells. J. Clin. Invest. 101: 153-159.

173. Marshall M. (1995) Interactions between ras and raf: key regulatory proteins in cellular transformation. Mol. Reprod. Dev. 42: 493-499.

174. Stokoe D, MacDonald SG, Cadwallader K, Symons M, Hancock JF. (1994) Activation of raf as a result of recruitment to the plasma membrane. Science 264: 1463-1467.
175. Sriuranpong V, Borges M, Ravi R, et al. (2001) Notch signaling induces cell cycle arrest in small cell lung cancer cells. Cancer Res. 61: 3200-3205.

176. Krystal GW, Hines SJ, Organ CP. (1996) Autocrine growth of small cell lung cancer mediated by coexpression of c-kit and stem cell factor. Cancer Res. 56: 370-376.

177. Wernert N, Raes MB, Lassalle PH, et al. (1992) c-ets-1 protooncogene is a transcription factor expressed in endothelial cells during tumor vascularization and other forms of angiogenesis in humans. Am. J. Pathol. 140: 119-127.

178. Wernert N, Gilles F, Fafeur V, et al. (1994) Stromal expression of c-ets 1 transcription factor correlates with tumor invasion. Cancer Res. 54: 5683-5688.

179. Bolon I, Gouyer V, Devouassoux M, et al. (1995) Expression of c-ets-1, collagenase 1 , and urokinase-type plasminogen activator genes in lung carcinomas. Am. J. Pathol. 147: 1298-1310.

180. Collins K, Mitchell JR. (2002) Telomerase in the human organism. Oncogene 21: 564-579.

181. Hiyama K, Hiyama E, Ishioka S, et al. (1995) Telomerase activity in small cell and non small cell lung cancer. J. Natl. Cancer Inst. 87: 895-902.

182. Hirashima T, Yoshitaka O, Nitta T, et al. (2001) Telomerase activity in endoscopically visible lung cancer. Anticancer Res. 21: $3685-3689$

183. Gomez-Roman JJ, Romero AF, Castro LS, Nieto EH, Fernandez-Luna JL, Val-Bernal JF. (2000) Telomerase activity in pulmonary neuroendocrine tumors: correlation with histologic subtype (MS-0060). Am. J. Surg. Pathol. 24: 417-421.

184. Champers AF, Matrisian LM. (1997) Changing views of the role of matrix metalloproteinases in metastasis. J. Natl. Cancer Inst. 17: 1260-1270.

185. Michael M, Babic B, Khokha R, et al. (1999) Expression and prognostic significance of metalloproteinases and their tissue inhibitors in patients with small cell lung cancer. J. Clin. Oncol. 17: 1802-1808.

186. Andreasen PA, Kjeller L, Christensen L, Duffy MJ. (1997) The urokinase-type plasminogen activator system in cancer metastasis: a review. Int. J. Cancer 72: 1-22.

187. Bolon I, Devouassoux M, Robert C, Moro D, Brambilla C, Brambilla E. (1997) Expression of urokinase-type plasminogen activator, stromelysin 1 , stromelysin 3, and matrilysin genes in lung carcinomas. Am. J. Pathol. 150: 1619-1629.

188. Robert C, Bolon I, Gazzeri S, Veyrenc S, Brambilla C, Brambilla E. (1999) Expression of plasminogen activator inhibitors 1 and 2 in lung cancer and their role in tumor progression. Clin. Cancer Res. 5: 2094-2102.

189. Tinnemans MMFJ, Lenders MJH, Ten Velde GPM, Blijham GH, Ramaekers FCS, Schutte B. (1999) Prognostic value of cytokinetic parameters in lung cancer after in vivo bromodeoxyuridine labelling. Anticancer Res. 19: 531-534.

190. Viren MM, Ojala AT, Kataja VV, Mattila JJ, Koivisto PA, Nikkanen VT. (1997) Flow cytometric analysis of tumor DNA profile related to response to treatment and survival in small cell lung cancer. Med. Oncol. 14: 35-38.

191. Bravo R, Frank R, Blundell PA, MacDonald-Bravo H. (1987) Cyclin/PCNA is the auxiliary protein of DNA polymerase delta. Nature 326: 515-517.

192. Brown DC, Gatter KC. (1991) Monoclonal antibody Ki-67: its use in histopathology. Histopathology 17: 489-503.

193. Bohm J, Koch S, Gais P, Jutting U, Prauer HW, Hofler H. (1996) Prognostic value of MIB-1 in neuroendocrine tumors of the lung. J. Pathol. 178: 402-409.

194. Arbiser ZK, Arbiser JL, Cohen C, Gal AA. (2001) Neuroendocrine lung tumors: grade correlates with proliferation but not angiogenesis. Mod. Pathol. 14: 1195-1199.

195. Tungekar MF, Gatter KC, Dunnill MS, Mason DY. (1991) Ki-67 immunostaining and survival in operable lung cancer Histopathology 19: 545-550.

196. Costes V, Marty-Ane C, Picot M, et al. (1995) Typical and atypical bronchopulmonary carcinoid tumors: a clinopathologic and Ki-67-labelling study. Hum. Pathol. 26: 740-745. 
197. Hanahan D, Folkman J. (1996) Patterns and emerging mechanisms of the angiogenic switch during tumorogenesis. Cell 86: $353-364$

198. Slodkowska J, Sikora J, Androsiuk W, Rudzinski P, Radomyski A. (1999) Lung carcinoids. Tumor angiogenesis in relation to clinopathologic characteristics. Anal. Quant. Cytol. Histol. 21: 267-272.

199. Eerola A, Soini Y, Paakko P. (2000) A high number of tumor-infiltrating lymphocytes are associated with a small tumor size, low tumor stage, and a favorable prognosis in operated small cell lung carcinoma. Clin. Cancer Res. 6: 1875-1881.

200. Dvorak HF, Brown LF, Detmar M, Dvorak AM. (1995) Vascular permeability of factor/vascular endothelial growth factor, microvascular hyperpermeability and angiogenesis. Am. J. Pathol. 146: 1029-1039.

201. Vaisman N, Gospodarowicz D, Neufeld G. (1990) Characterization of the receptors for vascular endothelial growth factor. J. Biol. Chem. 265: 19461-19469.

202. Matsuyama W, Hashiguchi T, Mizoguchi A, et al. (2000) Serum levels of vascular endothelial growth factor dependent on the stage progression of lung cancer. Chest 118: 948-951.

203. Marti HH, Risau W. (1998) Systemic hypoxia changes the organ-specific distribution of vascular endothelial growth factor and receptors. Proc. Natl. Acad. Sci. U. S. A. 95: 15809-15814.

204. Shen B, Lee DY, Gerber H, Keyr BA, Ferrara N, Zioncheck TF. (1998) Homologous up-regulation of KDR/Flk-1 receptor expression by vascular endothelial growth factor in vitro. J. Biol. Chem. 273: 29979-29985.

205. Lund EL, Thorsen C, Pedersen MWB, Junker N, Kristjansen PEG. (2000) Relationship between vessel density and expression of vascular endothelial growth factor and basic fibroblast growth factor in small cell lung cancer in vivo and in vitro. Clin. Cancer Res. 6: 4287-4291.

206. Salven P, Ruotsalainen T, Mattson K, Joensuu H. (1998) High pretreatment serum level of vascular endothelial growth factor (VEGF) is associated with poor outcome in small-cell lung cancer. Int. J. Cancer 79: 144-146.

207. Fontanini G, Faviana P, Lucchi M, et al. (2002) A high vascular count and overexpression of vascular endothelial growth factor are associated with unfavorable prognosis in operated small cell lung carcinoma. Br. J. Cancer 86: 558- 563.

208. Friesel RE, Maciag T. (1995) Molecular mechanisms of angiogenesis: fibroblast growth factor signaling transduction. FASEB J. 9: 919-925.

209. Asahara T, Bauters C, Zheng LP, et al. (1995) Synergistic effect of vascular endothelial growth factor and basic fibroblast growth factor on angiogenesis in vivo. Circulation 92: 365-371.

210. Ueno $K$, Inoue $Y$, Kawaguchi $T$, Hosoe $S$, Kawahara $M$. (2001) Increased serum levels of basic fibroblast growth factor in lung cancer patients: relevance to response of therapy and prognosis. Lung Cancer 31: 213-219.

211. Dameron KM, Volpert OV, Tainsky MA, Bouck N. (1994) Control of angiogenesis in fibroblasts by p53 regulation of thrombospondin-1. Science 265: 981-992.

212. Loeb LA. (1998) Cancer cells exhibit a mutator phenotype. Adv. Cancer Res. 72: 25-56.

213. Anbazhagan R, Tihan T, Bornman DM, et al. (1999) Classification of small cell lung cancer and pulmonary carcinoid by gene expression profiles. Cancer Res. 59: 5119-5122.

214. Sampietro G, Tomasic G, Collini P, et al. (2000) Gene product immunophenotyping of neuroendocrine lung tumors. No linking evidence between carcinoids and small-cell lung carcinomas suggested by multivariate statistical analysis. Appl. Immunohistochem. Mol. Morphol. 8: 49-56.

215. Colby TV, Wistuba II, Gazdar A. (1998) Precursors to pulmonary neoplasia. Adv. Anat. Pathol. 5: 205-215.

216. Kawanishi M, Kohno T, Otsuka T, et al. (1997) Allelotype and replication error phenotype of small cell lung carcinoma. Carcinogenesis 18: 2057-2062.

217. Carey FA, Prasad US, Walker WS, Cameron EWJ, Lamb D, Bird CC. (1992) Prognostic significance of tumor deoxyri- bonucleic acid content in surgically resected small-cell carcinoma of lung. J. Thorac. Cardiovasc. Surg. 103: 1214-1217.

218. Kimura T, Sato T, Onodera K. (1993) Clinical significance of DNA measurements in small cell lung cancer. Cancer 72: 3216-3222.

219. Abe S, Tsuneta $Y$, Makimura S, Itabishi $K$, Nagai $T$, Kawakami Y. (1987) Nuclear DNA content as an indicator of chemosensitivity in small cell carcinoma of the lung. Anal. Quant. Cytol. 9: 425-428.

220. El-Naggar A, Ballance W, Abdul Karim F, et al. (1991) Typical and atypical bronchopulmonary carcinoids: a clinopathologic and flow cytometric study. Am. J. Clin. Pathol. 95: 828-834.

221. Padberg BC, Woenckhaus J, Hilger G, et al. (1996) DNA cytophotometry and prognosis in typical and atypical bronchopulmonary carcinoids. A clinomorphologic study of 100 neuroendocrine lung tumors. Am. J. Surg. Pathol. 20: 8-15.

222. Redondo M, Concha A, Oldiviela R, et al. (1991) Expression of HLA class I and II antigens in bronchogenic carcinomas: its relationship to cellular DNA content and clinical-pathological parameters. Cancer Res. 51: 4948-4954.

223. York IA, Rock KL. (1996) Antigen processing and presentation by the class I major histocompatibility complex. Annu. Rev. Immunol. 14: 369-396.

224. Singal DP, Ye M, Ni J, Snider DP. (1996) Markedly decreased expression of TAP1 and LMP2 genes in HLA class Ideficient human tumor cell lines. Immunol. Lett. 50: 149-154.

225. Singal DP, Ye M, Qiu X. (1996) Molecular basis for lack of expression of HLA class I antigens in human small-cell lung carcinoma cell lines. Int. J. Cancer 68: 629-636.

226. Singal DP, Ye M, Bienzle D. (1998) Transfection of TAP gene restores HLA class I expression in human small-cell lung carcinoma. Int. J. Cancer 75: 112-116.

227. Yasumoto K, Takeo S, Yano T, et al. (1988) Role of tumorinfiltrating lymphocytes in the host defense mechanism against lung cancer. J. Surg. Oncol. 38: 221-226.

228. Kerr K, Johnson S, Kling J, Kennedy M, Weir J, Jeffrey R. (1998) Partial regression in primary carcinoma of the lung: does it occur? Histopathology 33: 55-63.

229. Eerola A, Soini Y, Paakko P. (1999) Tumor infiltrating lymphocytes in relation to tumor angiogenesis, apoptosis and prognosis in patients with large cell lung carcinoma. Lung Cancer 26: 73-84.

230. Nagata S., Golstein P. (1995) The Fas death factor. Science 267: 1449-1456.

231. Niehans GA, Brunner T, Frizelle SP, et al. (1997) Human lung carcinomas express fas ligand. Cancer Res. 57: 1007-1012.

232. Fischer J, Schindel M, Stein N, et al. (1995) Selective suppression of cytokine secretion in patients with small cell lung cancer. Ann. Oncol. 9: 921-926.

233. Vilcek J, Lee T. (1991) Tumor necrosis factor. J. Biol. Chem. 266: 7313-7316.

234. Haley KJ, Patidar K, Zhang F, Emanuel RL, Sunday ME. (1998) Tumor necrosis factor induces neuroendocrine differentiation in small cell lung cancer cell lines. Am. J. Physiol. 275: 311-321.

235. Kayser K, Gabius H, Gabius S, Hagemeyer O. (1992) Analysis of tumor necrosis factor- $\alpha$, lactose-specific and mistletoe lectin-specific binding sites at human lung carcinomas by labelled ligands. Virchows Arch. A Pathol. Anat. Histopathol. 421 : 345-349.

236. Shimura T, Hagihara M, Takebe K, et al. (1994) The study of tumor necrosis factor beta gene polymorphism in lung cancer patients. Cancer 73: 1184-1188.

237. Fischer J, Schindel M, Bulzebruck H, Lahm H, Krammer $P$, Drings P. (1997) Decrease of interleukin-2 secretion is a new independent prognostic factor associated with poor survival in patients with small-cell lung cancer. Ann. Oncol. 8: 457-461.

238. Fischer JR, Schindel M, Bulzebruck $H$, Lahm H, Krammer PH, Drings P. (2000) Long-term survival in small cell lung cancer patients is correlated with high interleukin-2 secretion at diagnosis. J. Cancer Res. Clin. Oncol. 126: 730-733.

239. Sarandakou A, Poulakis N, Rizos D, Trakakis E, Phocas I. (1993) Soluble interleukin-2 receptors (sIL-2r) and neuron 
specific enolase (NSE) in small cell lung carcinoma. Anticancer Res. 13: 173-176.

240. Zalcman G, Tredaniel J, Schlichtholz B, et al. (2000) Prognostic significance of serum p53 antibodies in patients with limited-stage small cell lung cancer. Int. J. Cancer 89: 81-86.

241. Mack U, Ukena D, Montenarh M, Sybrecht G. (2000) Serum anti-p53 antibodies in patients with lung cancer. Oncol. Rep. 7: 669-674.

242. Rosenfeld M, Malats N, Schramm L, et al. (1997) Serum anti-p53 antibodies and prognosis of patients with smallcell lung cancer. J. Natl. Cancer Inst. 89: 381-385.

243. Jassem E, Bigda J, Dziadziuszko R, et al. (2001) Serum p53 antibodies in small-cell lung cancer: the lack of prognostic relevance. Lung Cancer 31: 17-23.

244. Murray PV, Soussi T, O'Brien MER, et al. (2000) Serum p53 antibodies: predictors of survival in small-cell lung cancer? Br. J. Cancer 83: 1418-1424.

245. Stavrovskaya AA. (2000) Cellular mechanisms of multidrug resistance of tumor cells. Biochemistry (Mosc) 65: 95-106.

246. Rosenberg MF, Mao Q, Holzenburg A, Ford RC, Deeley RG, Cole SP. (2001) The structure of the multidrug resistence protein 1 (MRP1/ABCC1). Crystallization and single-particle analysis. J. Biol. Chem. 276: 16076-16082.

247. Zaman GJR, Flens MJ, van Leusden MR, et al. (1994) The human multidrug resistance-associated protein MRP is a plasma membrane drug-efflux pump. Proc. Natl. Acad. Sci. U. S. A. 91: 8822-8826.

248. Narasaki F, Matsuo I, Ikuno N, Fukuda M, Soda H, Oka M. (1996) Multidrug resistance-associated protein (MRP) gene expression in human lung cancer. Anticancer Res. 16: 2079-2082.

249. Young LC, Campling BG, Voskoglou-Nomikos T, Cole SPC, Deeley RG, Gerlach JH. (1999) Expression of multidrug resistance protein-related genes in lung cancer: Correlation with drug response. Clin. Cancer Res. 5: 673-680.

250. Bradley G, Juranka P, Ling V. (1988) Mechanism of multidrug resistance. Biochim. Biophys. Acta 948: 87-128.

251. Noonan KE, Beck C, Holzmayer TA, et al. (1990) Quantitative analysis of MDR 1 (multidrug resistance) gene expression in human tumors by polymerase chain reaction. Proc. Natl. Acad. Sci. U. S. A. 87: 7160-7164.

252. Milroy R, Plumb JA, Batstone P, et al. (1992) Lack of expression of P-glycoprotein in 7 small cell lung cancer cell lines established both from untreated and from treated patients. Anticancer Res. 12: 193-200.

253. Campling BG, Young LC, Baer KA, et al. (1997) Expression of the MRP and MDR 1 multidrug resistance genes in small cell lung cancer. Clin. Cancer Res. 3: 115-122.

254. Kreisholt J, Sorensen M, Jensen P, Andersen C, Sehested M. (1998) Immunohistochemical detection of DNA topoiso- merase II, P-glycoprotein and multidrug resistance protein (MRP) in small-cell and non-small-cell lung cancer. Br. J. Cancer 77: 1469-1473.

255. Holzmayer T, Hilsenbeck S, Von Hoff D, Roninson I. (1992) Clinical correlates of MDR I (P-glycoprotein) gene expression in ovarian and small-cell lung carcinomas. J. Natl. Cancer Inst. 84: 1486-1491.

256. Savaraj N, Wu C, Xu R, et al. (1997) Multidrug-resistant gene expression in small-cell lung cancer. Am. J. Clin. Oncol. 20: 398-403.

257. Poupon MF, Arvelo F, Goguel AF, et al. (1993) Response of small-cell lung cancer xenografts to chemotherapy: multidrug resistance and direct clinical correlates. J. Natl. Cancer Inst. 85: 2023-2029.

258. Zhang K, Mack P, Wong KP. (1998) Glutathione-related mechanisms in cellular resistance to anticancer drugs. Int. J. Oncol. 12: 871-882.

259. Cole SPC, Downes HF, Mirski SEL, Clements DJ. (1990) Alterations in glutathione and glutathione-related enzymes in a multidrug resistant small cell lung cancer cell line. Mol. Pharmacol. 37: 192-197.

260. Campling BG, Baer K, Baker HM, Lam YM, Cole SPC. (1993) Do glutathione and related enzymes play a role in drug resistance in small cell lung cancer cell lines? $\mathrm{Br}$. $J$. Cancer 68: 327-335.

261. Wang J. (1996) DNA topoisomerases. Annu. Rev. Biochem. 65: 635-692.

262. Hwang J, Hwong C. (1994) Cellular regulation of mammalian DNA topoisomerases. Adv. Pharmacol. 29A: 167-189.

263. Syahruddin $\mathrm{E}$, Oguri $\mathrm{T}$, Takahashi $\mathrm{T}$, Isobe $\mathrm{T}$, Fujiwara $\mathrm{Y}$, Yamakido M. (1998) Differential expression of DNA topoisomerase II $\alpha$ and II $\beta$ genes between small cell and nonsmall cell lung cancer. Jpn. J. Cancer Res 89: 855-861.

264. Giaccone G, Gazdar AF, Beck H, Zunino F, Capranico G. (1992) Multidrug sensitivity phenotype of human lung cancer cells associated with topoisomerase II expression. Cancer Res. 52: 1666-1674.

265. Withoff S, De Vries E, Keith W, et al. (1996) Differential expression of DNA topoisomerase II $\alpha$ and $-\beta$ in P-gp and MRP-negative VM26, mAMSA and mitoxantrone-resistant sublines of the human SCLC cell line $\mathrm{GLC}_{4}$. Br. J. Cancer $\mathbf{7 4}$ 1869-1876.

266. Resl M, Simek J, Bukac J, Rothrockel P, Siller J. (2001) DNA topoisomerase II-alpha in pulmonary carcinoid tumors. Pathol. Res. Pract. 197: 169-173.

267. Kasahara K, Fujiwara Y, Nishio K, et al. (1991) Metallothionein content correlates with the sensitivity of human small cell lung cancer cell lines to cisplatin. Cancer Res. 51: 3237-3242. 